\title{
Aerosol fluxes and particle growth above managed grassland
}

\author{
E. Nemitz ${ }^{1}$, J. R. Dorsey ${ }^{2}$, M. J. Flynn ${ }^{2}$, M. W. Gallagher ${ }^{2}$, A. Hensen ${ }^{3}$, J.-W. Erisman ${ }^{3}$, S. M. Owen ${ }^{1,4}$, U. Dämmgen ${ }^{5}$, \\ and M. A. Sutton ${ }^{1}$ \\ ${ }^{1}$ Centre for Ecology and Hydrology (Edinburgh), Bush Estate, Penicuik, Midlothian, EH26 0QB, UK \\ ${ }^{2}$ School for Earth, Atmospheric and Environmental Sciences, Univ. of Manchester, PO Box 88, Manchester, M60 1QD, UK \\ ${ }^{3}$ Energy Research Centre for the Netherlands (ECN), 1755-ZG Petten, The Netherlands \\ ${ }^{4}$ Institute for Environmental and Natural Sciences, University of Lancaster, UK \\ ${ }^{5}$ Institute for Agroecology, Federal Agricultural Research Centre, Braunschweig, Germany
}

Received: 13 October 2008 - Published in Biogeosciences Discuss.: 8 January 2009

Revised: 20 April 2009 - Accepted: 26 May 2009 - Published: 12 August 2009

\begin{abstract}
Particle deposition velocities (11-3000 nm diameter) measured above grassland by eddy covariance during the EU GRAMINAE experiment in June 2000 averaged 0.24 and $0.03 \mathrm{~mm} \mathrm{~s}^{-1}$ to long $(0.75 \mathrm{~m})$ and short $(0.07 \mathrm{~m})$ grass, respectively. After fertilisation with $108 \mathrm{~kg} \mathrm{Nha}^{-1}$ as calcium ammonium nitrate, sustained apparent upward fluxes of particles were observed. Analysis of concentrations and fluxes of potential precursor gases, including $\mathrm{NH}_{3}, \mathrm{HNO}_{3}$, $\mathrm{HCl}$ and selected VOCs, shows that condensation of $\mathrm{HNO}_{3}$ and $\mathrm{NH}_{3}$ on the surface of existing particles is responsible for this effect. A novel approach is developed to derive particle growth rates at the field scale, from a combination of measurements of vertical fluxes and particle size-distributions. For the first 9 days after fertilization, growth rates of $11 \mathrm{~nm}$ particles of $7.04 \mathrm{~nm} \mathrm{hr}^{-1}$ and $1.68 \mathrm{~nm} \mathrm{hr}^{-1}$ were derived for day and night-time conditions, respectively. This implies total $\mathrm{NH}_{4} \mathrm{NO}_{3}$ production rates of 1.11 and $0.44 \mu \mathrm{g} \mathrm{m}^{-3} \mathrm{~h}^{1}$, respectively. The effect translates into a small error in measured ammonia fluxes $(0.06 \%$ day, $0.56 \%$ night $)$ and a large error in $\mathrm{NH}_{4}^{+}$and $\mathrm{NO}_{3}^{-}$aerosol fluxes of $3.6 \%$ and $10 \%$, respectively. By converting rapidly exchanged $\mathrm{NH}_{3}$ and $\mathrm{HNO}_{3}$ into slowly depositing $\mathrm{NH}_{4} \mathrm{NO}_{3}$, the reaction modifies the total $\mathrm{N}$ budget, though this effect is small $(<1 \%$ for the 10 days following fertilization), as $\mathrm{NH}_{3}$ emission dominates the net flux. It is estimated that $3.8 \%$ of the fertilizer $\mathrm{N}$ was volatilised as $\mathrm{NH}_{3}$, of which $0.05 \%$ re-condensed to form $\mathrm{NH}_{4} \mathrm{NO}_{3}$ particles within the lowest $2 \mathrm{~m}$ of the surface layer. This surface induced process would at least scale up
\end{abstract}

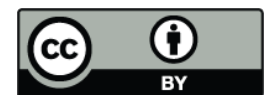

Correspondence to: E. Nemitz ( en@ceh.ac.uk) to a global $\mathrm{NH}_{4} \mathrm{NO}_{3}$ formation of ca. $0.21 \mathrm{kt} \mathrm{N} \mathrm{yr}^{-1}$ from $\mathrm{NH}_{4} \mathrm{NO}_{3}$ fertilisers and potentially $45 \mathrm{kt} \mathrm{N} \mathrm{yr}^{-1}$ from $\mathrm{NH}_{3}$ emissions in general.

\section{Introduction}

Aerosols make an important contribution to the Earth's radiation budget (IPCC, 2007). An important constituent of aerosols in this respect are hygroscopic compounds formed from anthropogenic precursors, such as ammonium sulphates $\left(\left(\mathrm{NH}_{4}\right)_{2} \mathrm{SO}_{4}, \mathrm{NH}_{4} \mathrm{HSO}_{4}\right)$, ammonium nitrate $\left(\mathrm{NH}_{4} \mathrm{NO}_{3}\right)$ and ammonium chloride $\left(\mathrm{NH}_{4} \mathrm{Cl}\right)$, which are formed by the neutralization of atmospheric ammonia $\left(\mathrm{NH}_{3}\right)$ by sulphuric acid $\left(\mathrm{H}_{2} \mathrm{SO}_{4}\right)$, nitric acid $\left(\mathrm{HNO}_{3}\right)$ and hydrochloric acid $(\mathrm{HCl})$, respectively. Adams et al. (2001) estimated presentday forcing potentials of sulphates and nitrates to be of the order of -0.95 and $-0.19 \mathrm{~W} \mathrm{~m}^{-2}$, respectively. In Europe sulphur (S) emissions have been reduced dramatically, by $61 \%$ over the period 1990 to 1998 (Vestreng and Støren, 2000), with the UK figure being 57\% (NEGTAP, 2001) and the German figure $84 \%$ (Umweltbundesamt, 2001). Similar trends are expected for other industrialised countries.

However, as with Germany, a decrease in sulphur emissions is not always mirrored by a decline in aerosol sulphate concentrations, which have been limited by $\mathrm{NH}_{3}$ emissions (Umweltbundesamt, 2001). European emissions of oxidized nitrogen $\left(\mathrm{NO}_{\mathrm{x}}\right)$ have declined very little and global $\mathrm{NO}_{\mathrm{x}}$ emissions are expected to increase. As a net result, for 2100 Adams et al. (2001) projected global sulphate forcing to decline to $-0.85 \mathrm{~W} \mathrm{~m}^{-2}$, while an increasing amount of the $\mathrm{NH}_{3}$ will be neutralized by $\mathrm{NO}_{\mathrm{x}}$, increasing the nitrate

Published by Copernicus Publications on behalf of the European Geosciences Union. 
forcing to $-1.28 \mathrm{~W} \mathrm{~m}^{-2}$. This prognosis is further supported by measurements that indicate that nitrates already dominate the light-scattering in the Netherlands, which are characterized by continental nitrate rich air masses and large $\mathrm{NH}_{3}$ emissions from high livestock densities (ten Brink et al., 1996).

In addition to the climate effect, the incorporation of relatively fast depositing reactive gaseous pollutants into small particles, that are deposited relatively inefficiently, increases the atmospheric lifetime and thus the transport distance of these acidifying and eutrophying pollutants. This obviously has important consequences for both local and national budgets and trans-boundary air pollutant transport (Sutton et al., 2007).

A third important effect of changes in the gas/aerosol partitioning concerns the applicability of methods to measure surface/atmosphere exchange fluxes. Micrometeorological flux measurement techniques are formulated for chemically inert tracers and have to be modified if a compound experiences sources or sinks within the atmosphere (e.g., Kramm et al., 1991). Under these conditions, the flux of a reactive tracer may change considerably with height and the vertical transport derived for a measurement height deviate from the true exchange at the surface. Unexpected observations have been made in a number of studies. Since $\mathrm{NH}_{3}$ exchange with vegetation is potentially bi-directional (e.g., Sutton et al., 1995, 2007), its a priori estimation is often uncertain. $\mathrm{HNO}_{3}$ and $\mathrm{HCl}$, however, are expected to deposit at the maximum deposition velocity permitted by turbulence $\left(V_{\max }\right)$, while particles deposit slowly to vegetation, at rates of typically $<1$ up to $5 \mathrm{~mm} \mathrm{~s}^{-1}$. Departures from these rates have been observed and attributed to gas-to-particle conversion or the evaporation of $\mathrm{NH}_{4}^{+}$aerosols (Huebert et al., 1988; Nemitz et al., 1996, 2002, 2004; van Oss et al., 1998).

The potential for formation of $\mathrm{NH}_{4} \mathrm{NO}_{3}$ and $\mathrm{NH}_{4} \mathrm{Cl}$ is most likely to be found near strong sources of either $\mathrm{NH}_{3}$ or the acids. Ammonia originates particularly from agricultural point sources such as cattle, pig and poultry units. A large fraction also originates from diffuse surface sources, such as the spreading of manure, organic or mineral fertilizers. These may either cause direct evaporation or raise the nutrient status of the crop or grassland resulting in a raised emission potential, or stomatal compensation point (e.g. Farquhar et al., 1980).

In May/June 2000 a major European integrated experiment, with 12 participating institutes, was organized to investigate $\mathrm{NH}_{3}$ exchange processes with managed agricultural grassland as part of the EU GRAMINAE project. The strategy of GRAMINAE has been described elsewhere, together with the set-up and overall results of this particular experiment (Sutton et al., 2001, 2008a, 2008b). During the campaign, the experimental grassland was cut, fertilised with $108 \mathrm{~kg} \mathrm{~N} \mathrm{ha}^{-1}$ as calcium ammonium nitrate and the course of grass regrowth followed.
As part of this experiment, particle number flux measurements were made by eddy-covariance above long grassland (before the cut), above short grassland (between cut and fertilization) and above the fertilized grassland, to study the behaviour of the aerosol and its interaction with the ammonia exchange. In addition to the observation of slow mean aerosol deposition fluxes to the unfertilized grassland, consistent diurnal patterns of apparent emissions were observed during the first 10 days following fertilization. The particle counter used for these measurements had a lower cut-off of $11 \mathrm{~nm}$ and an upper cut-off of effectively $3 \mu \mathrm{m}$. The observation of upward fluxes of particles could either be caused by the formation of new particles, which grow quickly to a size of $>11 \mathrm{~nm}$, or by the condensation of vapours on the surface of existing particles, resulting in the growth of some particles across the $11 \mathrm{~nm}$ threshold.

In this paper we represent the particle flux measurements and interpret the results in the context of simultaneous measurements of (i) fluxes of $\mathrm{NH}_{3}, \mathrm{HNO}_{3}$, and selected biogenic volatile organic compounds (BVOCs); (ii) concentrations of gaseous $\mathrm{SO}_{2}, \mathrm{HNO}_{3}$ and $\mathrm{HCl}$, as well as aerosol $\mathrm{NH}_{4}^{+}, \mathrm{NO}_{3}^{-}$, $\mathrm{Cl}^{-}$and $\mathrm{SO}_{4}^{2-}$; (iii) particle size spectra and (iv) meteorological parameters. A novel technique is developed to derive aerosol growth rates at the field scale from a combination of the particle number fluxes and aerosol size distributions. The overall objectives of this paper are:

(a) to quantify particle deposition velocities to (unfertilised) grassland;

(b) to identify the potential and mechanism of the particle production or growth following fertilisation;

(c) to quantify particle growth rates;

(d) to quantify the effect on the measurement of fluxes of $\mathrm{NH}_{3}$ and total nitrogen;

(e) to indicate the importance of surface ammonia emissions from fertilizer application for particle production globally.

\section{Methods and theory}

\subsection{Site description and overview of measurements}

The measurements were made above a 12 ha experimental agricultural grassland of the Agricultural Research Station Völkenrode near Braunschweig, Germany $\left(52^{\circ} 18^{\prime} \mathrm{N}\right.$, $10^{\circ} 26^{\prime} \mathrm{E}$; $79 \mathrm{~m}$ a.s.l.) during the period 21 May to 16 June 2000. The field was cut on 29 May (06:00-10:00 GMT) and fertilized on 5 June (06:00-07:00 GMT) with $108 \mathrm{~kg} \mathrm{~N} \mathrm{ha}^{-1}$ of calcium ammonium nitrate. The grass was mechanically turned in the morning of 30 May and lifted 31 May (06:0010:00 GMT). Canopy height before the cut was $\approx 0.75 \mathrm{~m}$ and 
after the cut $0.07 \mathrm{~m}$. The comprehensive set of instrumentation deployed has been summarized elsewhere (Sutton et al., 2008a; Nemitz et al., 2009a). We here focus on the description of those measurements related to the study of the gas/particle interaction.

Particle fluxes were made with an eddy-correlation system including a TSI condensation particle counter (TSI CPC 3760), with a sample flow rate of $11 \mathrm{~min}^{-1}$ and a size-range of $11 \mathrm{~nm}$ up to $3 \mu \mathrm{m}$, similar to the setups used by Dorsey et al. (2002) and Nemitz et al. (2002). A sonic anemometer (Model HS, Gill Instruments, UK) was mounted at a height of $2.02 \mathrm{~m}$. A stainless steel inlet (1/8" OD) led from just below the anemometer to the condensation particle counter, housed in a box at the foot of the measurement mast. The pulse output of the CPC was recorded on a PC based logging system at $10 \mathrm{~Hz}$, and fluxes were calculated according to standard eddy-covariance protocols (Dorsey et al., 2002). In addition, size-segregated particle fluxes over the range 0.1 to $0.4 \mu \mathrm{m}$ were measured at two different heights using optical particle counters, as presented elsewhere (Dorsey, 2002; Gallagher et al., 2002). The response time of the CPC is a little faster than $1 \mathrm{~Hz}$. Dorsey (2002) investigated the average co-spectra of the flux measurements and did not observe any appreciable deviation from the expected frequency dependence in the inertial subrange. Based on similar measurements, we estimate that the flux loss is likely to be $<30 \%$ for most conditions (Dorsey, 2002). No explicit correction is applied.

In addition, ammonia fluxes were measured by a total of four automated and continuous gradient systems (Milford et al., 2009) and four relaxed eddy accumulation systems (Hensen et al., 2008). Concentrations and gradients of gaseous $\mathrm{HNO}_{3}, \mathrm{HCl}, \mathrm{SO}_{2}$ and aerosol $\mathrm{NH}_{4}^{+}, \mathrm{NO}_{3}^{-}, \mathrm{Cl}^{-}$and $\mathrm{SO}_{4}^{2-}$ were measured above the grassland with a continuous sampling system combining wet annular denuders and steam jet aerosol collectors with online conductivity analysis for $\mathrm{NH}_{4}^{+}$and anion chromatography. The system (SJAC/WAD) was a forerunner of the GRAEGOR instrument described by Thomas et al. (2009), and differed from the GRAEGOR in that it used peristaltic pumps rather than syringe pumps to control the liquid flows. In brief, the system consists of two sampling boxes (SB, at $0.7 \mathrm{~m}$ and $2.0 \mathrm{~m}$ ) and a common detector box (DB). In each SB the gas phase is stripped from a $15 \mathrm{lpm}$ air sample through a continuously flushed wet annular rotating denuder, while the water soluble aerosol components are collected by passing the sample through steam and collecting the solution in a cyclone. The four channels (gas phase and aerosol phase at two heights) are alternately analysed online in the DB for anions by ion chromatography and for $\mathrm{NH}_{4}^{+}$with a selective ion membrane / conductivity detector. Continuous addition of an internal $\mathrm{Br}^{-}$standard ensures high precision between measurements. Fluxes were calculated according to the aerodynamic gradient technique as described by Milford et al. (2009) and Thomas et al. (2009).
The instrument was operated without a size-segregating cutoff inlet.

In addition, a combination of a tandem differential mobility analyzer (DMPS; Williams, 1999) and an Aerodynamic Particle Sizer (APS 3320, TSI, Minnesota, USA) was deployed to measure the particle size distribution over the range $3 \mathrm{~nm}$ to $20 \mu \mathrm{m}$ at a 10-min resolution. Additional information on the size distribution of the major ions was provided by MOUDI (Micro orifice uniform deposit impactor; MSP Corp., Minnesota, USA) runs, integrated over typically 3 days. In order to investigate the effect of the chemical interactions and deposition on concentrations of $\mathrm{NH}_{3}$ and acid gases, the background concentration of $\mathrm{NH}_{3}, \mathrm{HNO}_{3}$ and $\mathrm{HCl}$ were measured with an automated rotating wet batch denuder (RBD), providing 40-min batch samples in every hour (Keuken et al., 1988). This denuder was placed on the roof of a disused, $47 \mathrm{~m}$ tall building of the Physikalisch Technische Bundesanstalt (PTB), about $1 \mathrm{~km}$ ENE of the field site (see map in Sutton et al., 2008a). Daily concentrations of gases $\left(\mathrm{NH}_{3}, \mathrm{HNO}_{3}, \mathrm{HCl}, \mathrm{HNO}_{2}\right.$ and $\left.\mathrm{SO}_{2}\right)$ and aerosol components $\left(\mathrm{NH}_{4}^{+}, \mathrm{NO}_{3}^{-}, \mathrm{Cl}^{-}\right)$were also measured $250 \mathrm{~m}$ north of the grassland site, above wheat, using a KAPS (Kananaskis Air Pollutant Sampler) combination of 3-stage annular denuders and filter pack (PTFE, nylon) (e.g. Dämmgen, 2007). Throughflow was adjusted so that the cut-off point of KAPS is approx. $3 \mu \mathrm{m}$, and 24-h samples were taken between 00:00 and 24:00 h CET. Details of the experimental set-up, the sampling properties and quality parameters are described in Zimmerling et al. (1997). These samplers had shown to be reliable even under extreme weather conditions and yielded good results in sampler intercomparisons (e.g. Wiebe et al., 1990). Although the sampling height of $1.2 \mathrm{~m}$ was insufficient for concentrations to be fully unaffected by the atmosphere/surface exchange, these concentrations were not affected by the fertiliser application at the grassland site. Analysis was by liquid ion chromatography (IC) at FAL, Braunschweig for the KAPS samplers and at CEH Lancaster for the samples of MOUDI and RBD.

\subsection{Concentration and flux measurements of selected biogenic volatile organic compounds (BVOCs)}

The rationale behind the BVOC flux measurements was twofold: firstly, BVOCs potentially provide an alternative biogenically controlled precursor gas for particle formation and, secondly, high emissions of leaf alcohols from grass cutting have been reported in the literature (Kirstine et al., 1998; Karl et al., 2001). VOCs were collected onto Tenax TA $(200 \mathrm{mg})$ and Carbotrap $(100 \mathrm{mg})$ packed in steel tubes (6.1 mm OD, $90 \mathrm{~mm}$ length, Perkin Elmer). In the relaxed eddy accumulation (REA) approach (e.g., Desjardins, 1977), fast switching valves are used to sample air from up- and down-moving eddies conditionally onto two separate collection tubes. The valves were controlled by the switching logic of the CEH / UMIST REA system for atmospheric $\mathrm{NH}_{3}$ 
(Nemitz et al., 2001; Hensen et al., 2008), logging an ultrasonic anemometer (Solent R1012; Gill Instruments, Lymington, UK) at a rate of $20.83 \mathrm{~Hz}$. The sample tubes were tied directly onto the cage of the anemometer, operated at a height of $2.1 \mathrm{~m}$, to minimize flux losses, and mass flow controllers ensured a flow rate of $0.51 \mathrm{~min}^{-1}$, resulting in a total sample volume of approximately 151 per channel. Field blanks were taken by exposing a third tube at the same height, without flow. After sampling, tubes were sealed with Swagelok ${ }^{\circledR}$ end caps and Teflon ferrules and stored at $4^{\circ} \mathrm{C}$, under which conditions the analytes are stable for at least one week.

For gas chromatography-flame ionization detection (GCFID) analysis, tubes were desorbed using a Perkin-Elmer ATD-400 thermal desorption unit connected to a Hewlett Packard (HP) 5860 series II GC-FID. Separation of the compounds was achieved through the use of an Ultra-2 cross linked 5\% phenyl methyl silicone column. The detection limit for the monoterpenes is about $0.05 \mathrm{ng}$ for the column, corresponding to $40 \mathrm{ppt}$ in air for a 11 sample, with a level of analytical precision of better than $\pm 5 \%$.

For gas chromatography-mass spectrometry (GC-MS) analysis, a Perkin-Elmer ATD-400 thermal desorption unit is connected via a heated transfer line held at $200^{\circ} \mathrm{C}$ to a HP 5890 GC and a HP 5970 mass selective detector. Desorption, prefocussing and separation of the analytes is achieved using the same column and conditions as with the FID system. This system allows positive identification of a wide range of VOC on the basis of peak retention times, mass spectra contained in the library of the National Bureau of Standards and generated from authentic standards. Monoterpenes were quantified by preparing liquid standards by dilution of the pure compounds in methanol. Diluted standards $(1-5 \mu \mathrm{l})$ were directly injected onto sampling tubes and the methanol removed by passage of $\sim 0.31 \mathrm{He}$. Chromatographic data were handled with a VG Minichrom or HP system.

\subsection{Chemical reactions, equilibrium constants and time scales}

Ammonia reacts reversibly with nitric acid and hydrochloric acid to form the associated ammonium salts:

$$
\begin{aligned}
& \mathrm{NH}_{3}+\mathrm{HNO}_{3} \stackrel{K_{\mathrm{NH}_{4} \mathrm{NO}_{3}}}{\longleftrightarrow} \mathrm{NH}_{4} \mathrm{NO}_{3} \\
& \mathrm{NH}_{3}+\mathrm{HCl} \stackrel{K_{\mathrm{NH}_{4} \mathrm{Cl}}}{\longleftrightarrow} \mathrm{NH}_{4} \mathrm{Cl}
\end{aligned}
$$

The dissociation constants $\left(K_{\mathrm{NH}_{4} \mathrm{NO}_{3}}\right.$ and $\left.K_{\mathrm{NH}_{4} \mathrm{Cl}}\right)$ describe the equilibrium vapour concentration products $\left(K_{e}\right)$, which are expected to form if enough time is provided for aerosol and gas phase to equilibriate. Mozurkewich (1993) and Pio and Harrison (1987) provided expressions for $K_{e}$ as a function of temperature $(T)$ and relative humidity $(h)$ for pure $\mathrm{NH}_{4} \mathrm{NO}_{3}$ and $\mathrm{NH}_{4} \mathrm{Cl}$, respectively. While this is generally applicable to solid aerosol, deliquescent aerosols represent mixed aqueous solutions, for which the equilibrium vapour concentration is lowered compared with pure solutions, especially by the presence of sulphates (e.g., Stelson and Seinfeld, 1982). For ultrafine particles, partial pressures may be elevated by the Kelvin effect. The effective vapour concentrations in equilibrium with an externally mixed aerosol consisting of different types and sizes is impossible to predict exactly. $K_{e}$ is a good approximation for humidities below the relative humidity of deliquescence (about $80 \%$ for $\left(\mathrm{NH}_{4}\right)_{2} \mathrm{SO}_{4}$ and $60 \%$ for $\mathrm{NH}_{4} \mathrm{NO}_{3}$ ). Whether equilibrium is attained depends on the comparative timescales of attainment of equilibrium $\left(\tau_{c}\right)$ and the processes perturbing equilibrium, including turbulent diffusive transport $\left(\tau_{t}\right)$. Conversely, the Damköhler ratio $\left(D_{r}=\tau_{t} / \tau_{c}\right)$ is also a measure of the degree to which chemical conversions may affect surface / atmosphere exchange fluxes (Foken et al., 1995). Expressions for $\tau_{c}$ and $\tau_{t}$ can be found elsewhere (e.g., Wexler and Seinfeld, 1990, 1991), as summarized by Nemitz et al. (2000).

\subsection{A novel method for the calculation of growth rates from particle flux measurements at the field scale}

As shown in the Results Section below, the measured timeseries of particle fluxes changed from mainly small deposition prior to fertilization, to clear diurnal cycles with consistent and significant apparent upward fluxes after fertilization. As discussed below, this behaviour is attributed to particle growth during deposition. Where particles grow during the deposition process, e.g. due to uptake of secondary aerosol products or due to water uptake, this particle growth implies that some particles will grow across the lower cut-off of the particle counter $\left(d_{p}=11 \mathrm{~nm}\right)$ as they deposit. As a result the concentration of particles $>11 \mathrm{~nm}$ may increase towards the ground at the same time as the total number of particles decreases due to deposition. In this Section we show that this growth can result in a situation where eddy-covariance may derive an apparent upward flux of particles $>11 \mathrm{~nm}$. We also develop the mathematical concepts to relate the apparent emission flux to the growth rate of the particles.

The equation of mass conservation of a tracer $(\chi)$ is given by (e.g. Fowler and Duyzer, 1989):

$\frac{\partial F_{\chi}}{\partial z}=-\frac{\partial \chi}{\partial t}+\bar{u} \frac{\partial \chi}{\partial x}+\bar{w} \frac{\partial \chi}{\partial z}+Q_{\chi}$,

where $F_{\chi}$ is the vertical flux of the tracer, $t$ is time, $u$ and $w$ are the wind components along the stream-wise and vertical co-ordinates ( $x$ and $z$ ), and $Q_{\chi}$ represents in situ production/destruction of the tracer. The right-hand-side (r.h.s.) terms represent:

1. Storage is linked to the change in concentration with time $(\partial \chi / \partial t)$, this change in concentration requires material, which needs to be balanced by the other terms of the equation. This term vanishes in stationary conditions. 
2. Horizontal advection is linked to the mean horizontal wind speed, coupled to a horizontal concentration gradient $(\partial \chi / \partial x)$ and is usually minimized by selecting conditions where concentrations are horizontally homogeneous.

3. Vertical advection is linked to the mean vertical wind component, coupled to a vertical concentration gradient $(\partial \chi / \partial z)$. Normally, eddy-covariance measurements are designed so that the vertical mean wind component is zero.

4. The additional source/sink term $\left(Q_{\chi}\right)$ describes externally driven changes to the mass budget. It often describes the production $\left(Q_{\chi}>0\right)$ or destruction $\left(Q_{\chi}>0\right)$ due to chemistry or emissions at the point of measurement.

Thus, under the assumptions of stationary and homogeneous conditions typical for micrometeorological flux measurements over large fields, the terms (i) to (iii) vanish. If we consider particle number concentration $(N)$ within the sizerange of the CPC as the tracer, the growth into or out of the size range represent an external source/sink term, which may be written as $Q_{N}=\mathrm{d} N / \mathrm{d} t$. Despite the similarity to the storage term (i) of Eq. (1), this represents an external production rather than changes in concentration due to storage of particles within the size range. Thus, for particle number fluxes measured within the size bin of the CPC $\left(11 \mathrm{~nm}<d_{p}<\right.$ $3 \mu \mathrm{m}), Q_{N}$ is related to external effects that change the concentration within this size bin only:

$\frac{\mathrm{d} F_{\mathrm{N}}\left(11 \mathrm{~nm}<d_{\mathrm{p}}<3 \mu \mathrm{m}\right)}{\mathrm{d} z}=\frac{\mathrm{d} N\left(11 \mathrm{~nm}<d_{\mathrm{p}}<3 \mu \mathrm{m}\right)}{\mathrm{d} t}$

This term describes effects due to the growth/shrinkage across the lower or upper size cuts, direct emissions of particles within the size range and, potentially, number reduction due to coagulation. We here assume that there are no emissions sources at the point of measurement and that coagulation is unimportant (see discussion below). Thus the change in $N\left(11 \mathrm{~nm}<d_{\mathrm{p}}<3 \mu \mathrm{m}\right)$ is only affected by the growth into the size range over the lower size-cut and growth out of the size range across the upper size cut. After application of the chain rule for forming derivatives the vertical flux divergence can be expressed as:

$\frac{\mathrm{d} F_{\mathrm{N}}}{\mathrm{d} z}=\frac{\mathrm{d} N}{\mathrm{~d} d_{\mathrm{p}}}\left|d_{\mathrm{p}}=11 \mathrm{~nm} \times \frac{\mathrm{d} d_{\mathrm{p}}}{\mathrm{d} t}\right| d_{\mathrm{p}}=11 \mathrm{~nm}\left(-\frac{\mathrm{d} N}{\mathrm{~d} d_{\mathrm{p}}}\left|d_{\mathrm{p}}=3 \mu \mathrm{m} \times \frac{\mathrm{d} d_{\mathrm{p}}}{\mathrm{d} t}\right| d_{\mathrm{p}}=3 \mu \mathrm{m}\right)$

Here $F_{\mathrm{N}}$ and $N$ are particle number flux and number concentration in the size range $11 \mathrm{~nm}$ to $3 \mu \mathrm{m}$, respectively. The (non-logarithmic) particle size distribution function $\left(\mathrm{d} N / \mathrm{d} d_{\mathrm{p}}\right)$ at $d_{\mathrm{p}}=11 \mathrm{~nm}$ and $d_{\mathrm{p}}=3 \mu \mathrm{m}$ can be measured directly with appropriate instrumentation. Owing to the small number concentration of super-micron particles, the second r.h.s. term, i.e. the growth across the $3 \mu \mathrm{m}$ threshold can be neglected. The growth rate $\left(\mathrm{d} d_{p} / \mathrm{d} t\right)$ can be expressed as (Kulmala et al., 2001):

$\frac{\mathrm{d} d_{\mathrm{p}}}{\mathrm{d} t}=\frac{4 m_{v} \beta_{\mathrm{m}} D \chi_{\mathrm{v}}}{d_{\mathrm{p}} \rho_{\mathrm{p}}}$

where $m_{\mathrm{v}}$ and $\chi_{\mathrm{v}}$ are the molecular mass and effective concentration of the condensable vapour, respectively, and $\rho_{\mathrm{p}}$ is the particle density, while $\beta_{\mathrm{m}}$ is the correction factor for mass flux in the transition regime (Fuchs and Sutugin, 1971):

$\beta_{\mathrm{m}}=\frac{K_{\mathrm{n}}+1}{0.337 K_{\mathrm{n}}+1+4 / 3 \alpha^{-1} K_{\mathrm{n}}}$

Here $K_{\mathrm{n}}$ is the Knudsen number

$K_{\mathrm{n}}=\frac{2 \lambda}{d_{\mathrm{p}}}$

with $\lambda$ being the mean molecular free path in air $(0.065 \mu \mathrm{m})$. Research suggests that the sticking coefficient $(\alpha)$ for $\mathrm{NH}_{3} / \mathrm{HNO}_{3}$ is in the range 0.3 to 1 (Dassios and Pandis, 1999; Cruz et al., 2000; Rudolf et al., 2001); here $\alpha=0.5$ is used, which results in a value of $\beta_{m}=0.031$ for $d_{\mathrm{p}}=11 \mathrm{~nm}$ and $\beta_{\mathrm{m}}=0.918$ for $d_{\mathrm{p}}=3 \mu \mathrm{m}$. $D$ in Eq. (4) is the binary diffusion coefficient for vapour diffusion towards a particle (Reid et al., 1987):

$D=\frac{R T}{3 \pi N_{\mathrm{A}} v d_{\mathrm{p}}}$

Here, $R$ is the universal gas constant, $T$ is temperature in $\mathrm{K}, N_{\mathrm{A}}$ is the Avogadro constant and $v$ is the gas dynamic viscosity.

Usually, the equation for the vertical flux divergence (Eq. 1) is used to derive the surface flux by correcting the flux measured at some height for the processes described by the right-hand-side terms. The absolute difference between measured and surface flux is obtained by integration of Eq. (1) between surface and measurement height. Here we invert this process to estimate the vertical flux divergence from the difference between the expected flux at the surface and the measured flux at the measurement height. The surface flux may be estimated as

$F_{\mathrm{s}}=-V_{\mathrm{d}}\left(z_{\mathrm{m}}\right) \chi_{\mathrm{N}}\left(z_{\mathrm{m}}\right)$,

where $\chi_{\mathrm{N}}\left(z_{\mathrm{m}}\right)$ is the number concentration in the CPC size range at the measurement height $\left(z_{\mathrm{m}}\right)$ and $V_{\mathrm{d}}\left(z_{\mathrm{m}}\right)$ is the deposition velocity expected in the absence of chemical reactions. Here $V_{\mathrm{d}}$ was parameterised using an average deposition velocity $\left(V_{\mathrm{d}}=-F_{\mathrm{N}} / \chi_{\mathrm{N}}\right)$ of $0.24 \mathrm{~mm} \mathrm{~s}^{-1}$ derived from the CPC flux measurements before fertilization, when there was no evidence for particle growth affecting the flux measurement (cf. Sect. 3.1 below). The average flux divergence between 


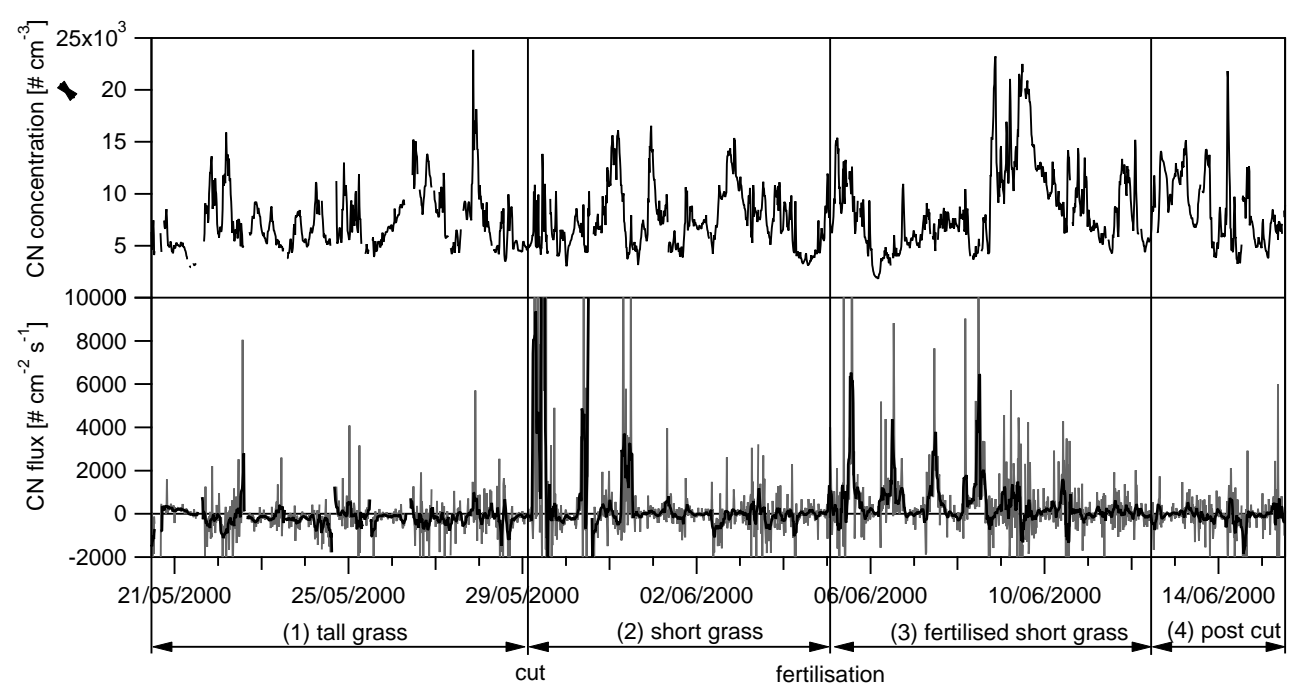

Fig. 1. Time-series of the particle number concentration and fluxes of particles (condensation nuclei, CN) measured with the CPC flux system $(11 \mathrm{~nm}$ to $\approx 3 \mu \mathrm{m})$.

Table 1. Summary of the statistics of the concentrations and fluxes measured with the CPC system before the cut and after fertilisation (based on 30-min flux values).

\begin{tabular}{|c|c|c|c|c|c|c|c|c|c|c|c|c|}
\hline \multirow{4}{*}{$\begin{array}{l}\text { Mean } u_{*}\left[\mathrm{~m} \mathrm{~s}^{-1}\right] \\
\text { Mean } H\left[\mathrm{~W} \mathrm{~m}^{-2}\right]\end{array}$} & \multirow{3}{*}{\multicolumn{3}{|c|}{$\begin{array}{c}\text { Period (1): } \\
\text { before cut } \\
0.25 \\
-4.2\end{array}$}} & \multirow{2}{*}{\multicolumn{3}{|c|}{$\begin{array}{c}\text { Period (2): } \\
\text { after cut, before fertilisation } \\
0.21\end{array}$}} & \multicolumn{3}{|c|}{$\begin{array}{c}\text { Period (3): } \\
\text { directly after fertilisation }\end{array}$} & \multicolumn{3}{|c|}{$\begin{array}{c}\text { Period (4): } \\
\text { 7-10 days after fertilisation }\end{array}$} \\
\hline & & & & & & & & 0.21 & & & 0.23 & \\
\hline & & & & & 44.0 & & & 31.6 & & & 35.3 & \\
\hline & $\begin{array}{l}\chi_{\mathrm{N}} \\
{\left[\# \mathrm{~cm}^{-3}\right]}\end{array}$ & $\begin{array}{l}F_{\mathrm{N}} \\
{\left[\# \mathrm{~cm}^{-2} \mathrm{~s}^{-1}\right]}\end{array}$ & $\begin{array}{l}V_{\mathrm{d}} \\
{\left[\mathrm{mm} \mathrm{s}^{-1}\right]}\end{array}$ & $\begin{array}{l}\chi_{\mathrm{N}} \\
{\left[\# \mathrm{~cm}^{-3}\right]}\end{array}$ & $\begin{array}{l}F_{\mathrm{N}} \\
{\left[\# \mathrm{~cm}^{-2} \mathrm{~s}^{-1}\right]}\end{array}$ & $\begin{array}{l}V_{\mathrm{d}} \\
{\left[\mathrm{mm} \mathrm{s}^{-1}\right]}\end{array}$ & $\begin{array}{l}\chi_{\mathrm{N}} \\
{\left[\# \mathrm{~cm}^{-3}\right]}\end{array}$ & $\begin{array}{l}F_{\mathrm{N}} \\
{\left[\# \mathrm{~cm}^{-2} \mathrm{~s}^{-1}\right]}\end{array}$ & $\begin{array}{l}V_{\mathrm{d}} \\
{\left[\mathrm{mms}^{-1}\right]}\end{array}$ & $\begin{array}{l}\chi_{\mathrm{N}} \\
{\left[\# \mathrm{~cm}^{-3}\right]}\end{array}$ & $\begin{array}{l}F_{\mathrm{N}} \\
{\left[\# \mathrm{~cm}^{-2} \mathrm{~s}^{-1}\right]}\end{array}$ & $\begin{array}{l}V_{\mathrm{d}} \\
{\left[\mathrm{mm} \mathrm{s}^{-1}\right]}\end{array}$ \\
\hline Min & 2903 & -4080 & -5.39 & 3004 & -3950 & -11.7 & 1800 & -5790 & -10.8 & 3231 & -4250 & -10.8 \\
\hline $\operatorname{Max}$ & 23840 & 5700 & 4.34 & 16526 & 5820 & 6.69 & 23230 & 9020 & 9.26 & 21803 & 6000 & 4.80 \\
\hline $5 \%$-ile & 4303 & -1340 & -0.98 & 3831 & -1110 & -1.70 & 3776 & -1090 & -3.17 & 4108 & -1160 & -1.28 \\
\hline $95 \%$-ile & 12930 & 718 & 1.74 & 13850 & 1220 & 1.56 & 17510 & 2570 & 1.11 & 13724 & 992 & 1.53 \\
\hline Mean & 7190 & -181 & 0.24 & 7611 & -17 & 0.03 & 8628 & 323 & -0.46 & 8301 & -63 & 0.06 \\
\hline Median & 6486 & -151 & 0.24 & 7057 & -45 & 0.06 & 7689 & 85 & -0.13 & 7612 & -44 & 0.05 \\
\hline Standard dev. & 2665 & 710 & 0.95 & 2920 & 857 & 1.37 & 4146 & 1220 & 1.48 & 3265 & 835 & 1.15 \\
\hline $\begin{array}{l}\text { frequency of } \\
\text { emission [\%] }\end{array}$ & & 31 & & & 42 & & & 60 & & & 43 & \\
\hline $\mathrm{N}$ & 714 & 701 & 701 & 636 & 580 & 580 & 612 & 598 & 598 & 295 & 290 & 290 \\
\hline
\end{tabular}

the ground and $z_{\mathrm{m}}\left(\mathrm{d} F_{\mathrm{N}} / \mathrm{d} z\right)$ may be calculated from the difference between measured flux $\left(F_{\mathrm{N}}\right)$ and $F_{\mathrm{s}}$, divided by $z_{\mathrm{m}}$ :

$\frac{\mathrm{d} F_{\mathrm{N}}}{\mathrm{d} z}=\frac{F_{\mathrm{N}}-F_{\mathrm{s}}}{z_{\mathrm{m}}}$

With Eqs. (3) and (9), the growth rate across the size cut-off of the particle counter (i.e. $\mathrm{d} d d_{\mathrm{p}} / \mathrm{d} t$ at $d_{\mathrm{p}}=11 \mathrm{~nm}$, in $\mathrm{nm} \mathrm{hr}{ }^{-1}$ ) can be estimated from the measured fluxes and particle size spectra. By inverting Eq. (4), the effective vapour concentration available for condensation $\left(\chi_{\mathrm{v}}\right)$ can be derived. The growth rate across the $11 \mathrm{~nm}$ threshold may be extrapolated to derive the growth rate of all particle sizes, again using Eq. (4). The total mass transport from the gas to the particle phase $\left(j_{\mathrm{v}}\right)$ is then given by integration over all size classes $(i)$ as:

$j_{\mathrm{v}}=\sum_{i=1}^{n} \pi d_{\mathrm{i}}^{2} N_{\mathrm{i}} \mathrm{g} \frac{\rho_{\mathrm{p}}}{2 m_{\mathrm{v}}} \frac{\mathrm{d} d}{\mathrm{~d} t}$ where the particle density $\left(\rho_{\mathrm{p}}\right)$ is set to that of $\mathrm{NH}_{4} \mathrm{NO}_{3}$ for consistency. Assuming the mass transport to be due to the combined condensation of $\mathrm{NH}_{3}$ and $\mathrm{HNO}_{3}, 21.25 \%$ of $j_{\mathrm{v}}$ (in terms of mass) is due to the condensation of $\mathrm{NH}_{3}$.

\section{Results}

\subsection{Particle number flux measurements before and af- ter fertilisation}

The measured particle number unfiltered flux is shown in Fig. 1. Spikes are primarily due to emissions associated with the operations of agricultural machinery in the field (e.g. cutting on 29 May, turning of the cut grass 30 May and removal of the cut grass on 1 June). Otherwise, the measurement show small fluxes, dominated by deposition before the fertilisation, 
and a diurnal pattern of apparent emission fluxes after fertilisation, which slowly subsided.

The statistics of the concentrations and fluxes before and after fertilisation are summarised in Table 1, after management periods had been removed and data filtered for suitable wind directions. Mean air concentrations were similar during the four periods, ranging from 7190 to $8628 \mathrm{~cm}^{-3}$. Both emission and deposition fluxes were measured during all four periods, but were least frequent (occurring $31 \%$ of the time) before the cut and most frequent (occurring 60\% of the time) during the first week after fertilization. The average apparent emission flux after fertilization was larger than the deposition fluxes to the short vegetation. The average (median) deposition velocities were $0.24(0.24) \mathrm{mm} \mathrm{s}^{-1}$ before the cut (Period 1), 0.03 (0.06) $\mathrm{mm} \mathrm{s}^{-1}$ between cut and fertilization (Period 2) and $0.06(0.05) \mathrm{mm} \mathrm{s}^{-1} 7-10$ days after fertilization (Period 4), qualitatively consistent with the known dependence of deposition velocities on surface roughness (e.g., Gallagher et al., 2002). The different measurement periods were very similar in terms of $u_{*}$ and sensible heat fluxes $(H)$, with slightly reduced values of $H$ during Period (1) reflecting lower solar radiation.

\subsection{Atmospheric concentrations, equilibrium consider- ations and potential for $\mathrm{NH}_{4} \mathrm{NO}_{3}$ formation}

The time-series of the concentration in air of $\mathrm{NH}_{3}, \mathrm{HNO}_{3}$ and $\mathrm{HCl}$ at $1 \mathrm{~m}$ and $47 \mathrm{~m}$ are presented in Fig. 2, clearly showing the effect of fertilisation on the concentration of $\mathrm{NH}_{3}$. The average $\mathrm{NH}_{3}$ concentration at the notional canopy height $\left(z_{0}\right.$ ') can be estimated from the additional knowledge of the $\mathrm{NH}_{3}$ flux ( $F_{\mathrm{NH} 3}$; Fig. 2c) (Sutton et al., 1993; Milford et al., 2008), under the simplifying assumption that the flux is unaffected by the chemical conversion:

$\chi_{\mathrm{NH}_{3}}\left(z_{0}^{\prime}\right)=\chi_{\mathrm{NH}_{3}}(1 \mathrm{~m})+F_{\mathrm{NH}_{3}}\left[R_{\mathrm{a}}(1 \mathrm{~m})+R_{\mathrm{b}}\right]$

Here $R_{\mathrm{a}}$ and $R_{\mathrm{b}}$ are the aerodynamic sub-layer resistance describing the transport through the turbulent and the quasilaminar part of the atmosphere, respectively. This concentration is also shown in Fig. 2b for comparison. All concentrations undergo a clear diurnal cycle, with daytime maxima. Both acids are depleted over the first two days after fertiliser application on the morning of 5 June. However, this change is also reflected in the background gas measurements (Fig. 2; both by RBD and KAPS). This indicates that this decrease is not due to a mechanism that is confined to the fertilized field, e.g. the depletion by reaction with $\mathrm{NH}_{3}$ from fertilizer emissions. Instead, the decrease in $\mathrm{HNO}_{3}$ appears to reflect changes in air masses or regional chemistry.

$\chi_{\mathrm{NH}_{3}}\left(z_{0}{ }^{\prime}\right)$ exhibits the behaviour expected for a gas concentration that is governed by equilibrium with dry or aqueous $\mathrm{NH}_{4}^{+}$, with the diurnal pattern reflecting the temperature control and the long-term decrease in soil and plant $\mathrm{NH}_{4}^{+}$after fertilization (cf. Milford et al., 2001; Sutton et
Table 2. Summary of the concentrations and fluxes of selected VOCs (averages of 91 -hr runs between cutting and fertilization and 5 1-hr runs after fertilization).

\begin{tabular}{lrrrr}
\hline & \multicolumn{2}{c}{$\begin{array}{c}\text { Concentration }\left[\mathrm{ng} \mathrm{m}^{-3}\right] \\
\text { before }\end{array}$} & $\begin{array}{c}\text { Flux }\left[\mathrm{ng} \mathrm{m}^{-2} \mathrm{~s}^{-1}\right] \\
\text { after }\end{array}$ & $\begin{array}{c}\text { before } \\
\text { fertilization }\end{array}$ \\
& \multicolumn{2}{c}{ fertilization } & & \\
\hline Benzaldehyde & $5400( \pm 220)$ & $5700( \pm 430)$ & $-140( \pm 69)$ & $-250( \pm 61)$ \\
Nonanal & $590( \pm 22)$ & $650( \pm 73)$ & $14( \pm 8.0)$ & $7.6( \pm 16)$ \\
$\alpha$-Pinene & $84( \pm 9.8)$ & $47( \pm 4.6)$ & $1.9( \pm 0.6)$ & $1.4( \pm 1.1)$ \\
1- $\beta$-Pinene & $75( \pm 2.6)$ & $97( \pm 26)$ & $-0.33( \pm 1.0)$ & $14( \pm 16)$ \\
d-3-Carene & $290( \pm 7.4)$ & $300( \pm 28)$ & $-4.3( \pm 3.6)$ & $8.6( \pm 8.4)$ \\
\hline
\end{tabular}

al., 2008b). On an equivalent basis, $\mathrm{NH}_{4}^{+}$aerosol concentrations exceeded the $\mathrm{NO}_{3}^{-}$concentrations by a factor of two (Fig. 3), the rest of the $\mathrm{NH}_{4}^{+}$being neutralized by $\mathrm{SO}_{4}^{2-}$ (not shown). The measurements indicated that $\mathrm{NO}_{3}^{-}$concentrations appeared to be increased at the grassland site, compared with the control site $400 \mathrm{~m}$ to the north. However, this observation was also made prior to fertilization and may at least be partially due to a larger cut-off diameter of the SJAC capturing additional coarse $\mathrm{NO}_{3}^{-}$compared with the KAPS.

The comparison of measured $\left(K_{\mathrm{m}}\right)$ with theoretical equilibrium $\left(K_{\mathrm{e}}\right)$ vapour concentration products of $\mathrm{NH}_{3}$ with the acids shows $K_{\mathrm{m}}<<K_{\mathrm{e}}$ prior to fertilizer application (Fig. 4). Since the $\mathrm{NH}_{3}$ concentration above the grassland increased on 5 June, measured products $\left[\mathrm{NH}_{3}\right] \times[\mathrm{HCl}]$ increased also, but were still much smaller than $K_{e}$. Measured products of $\left[\mathrm{NH}_{3}\right] \times\left[\mathrm{HNO}_{3}\right]$ were close to their theoretical equilibrium values during 5 to 11 June with exceedances during most nights.

\subsection{Concentrations and fluxes of VOCs}

Out of the 27 hourly VOC REA runs performed, at total of 14 runs were selected for analysis for a limited suite of oxygenated compounds and terpenoids (benzaldehyde, nonanal, $\alpha$-pinene, $1-\beta$-pinene and $\mathrm{d}$-3-carene). Grass cutting has been found to increase emissions of some BVOCs by a factor of 180 (Kirstine et al., 1998; Karl et al., 2001), but the leaf alcohols, the primary BVOCs released, are not very efficient particle precursors until they are processed to form less volatile compounds. By constrast, biogenic alkenes have been found to be efficient aerosol precursors (e.g., Hoffmann et al., 1997). The suite of VOCs was selected to provide information on the magnitude of emissions allowing the estimation of their potential for particle formation/particle growth. Averaged concentrations and fluxes after the cut and before fertilization are contrasted with the measurements after fertilization in Table 2. The flux measurements should be interpreted with caution. However, neither concentrations nor fluxes show significant changes before and after fertilization. Irrespective of fertilization, benzaldehyde showed a clear diurnal cycle with daytime maxima of $8 \mu \mathrm{g} \mathrm{m}^{-3}$ and night-time minima of $2 \mu \mathrm{g} \mathrm{m}^{-3}$ (not shown). 


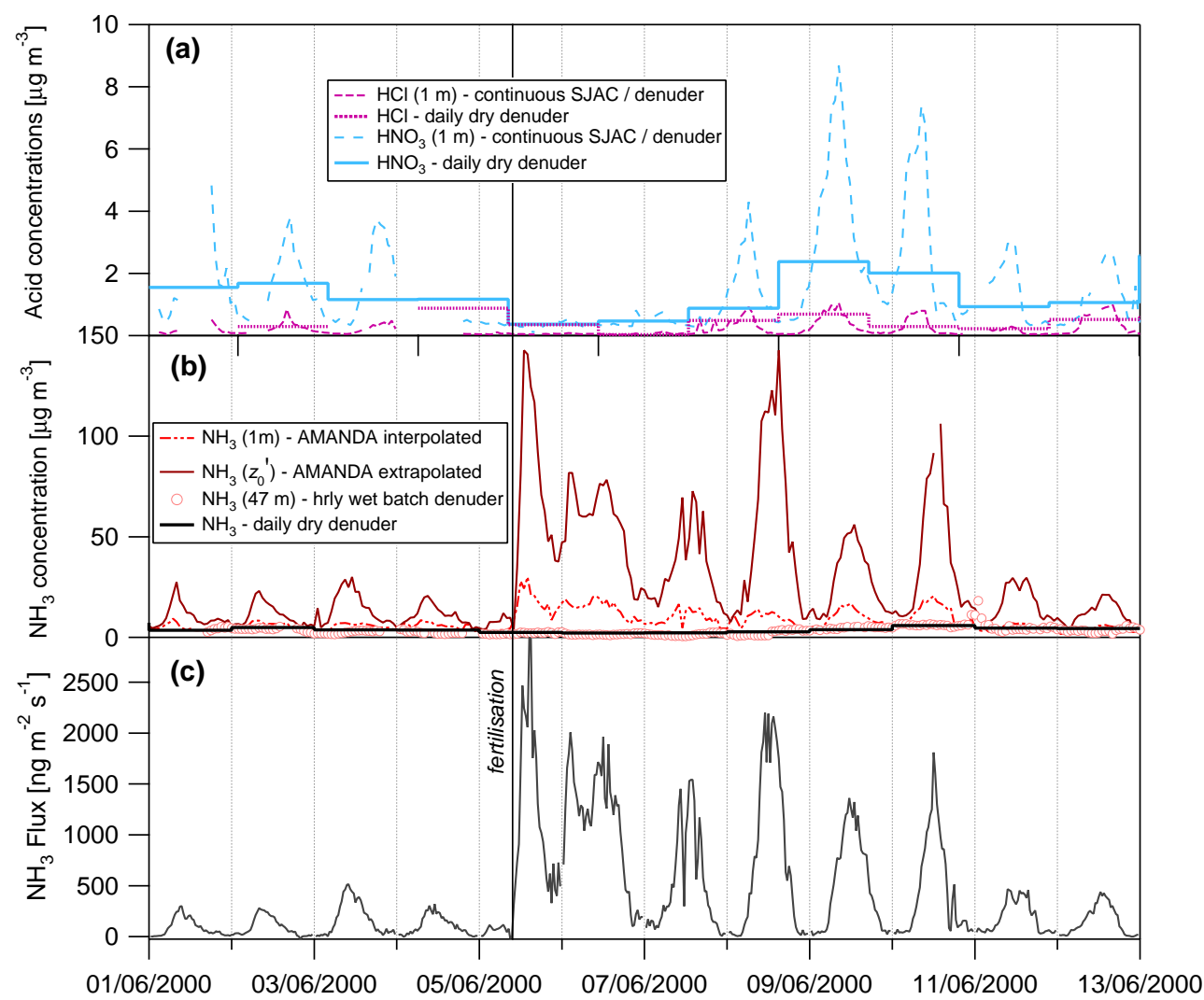

Fig. 2. Evolution of the gas concentrations of (a) $\mathrm{HCl}$ and $\mathrm{HNO}_{3}$ and (b) $\mathrm{NH}_{3} 1 \mathrm{~m}$ and $47 \mathrm{~m}$ above the grassland, compared with the $\mathrm{NH}_{3}$ concentration extrapolated to the canopy $\left(\mathrm{NH}_{3}\left(z_{0}\right.\right.$ ')). (c) Flux of $\mathrm{NH}_{3}$. The fertilizer was applied on 5 June 08:00 to 10:00 GMT. The concentrations and fluxes of $\mathrm{NH}_{3}$ are based on the best estimate $\chi \mathrm{NH}_{3}$ and $F_{\mathrm{NH}_{3}}$ provided by Milford et al. (2008). See text for details.

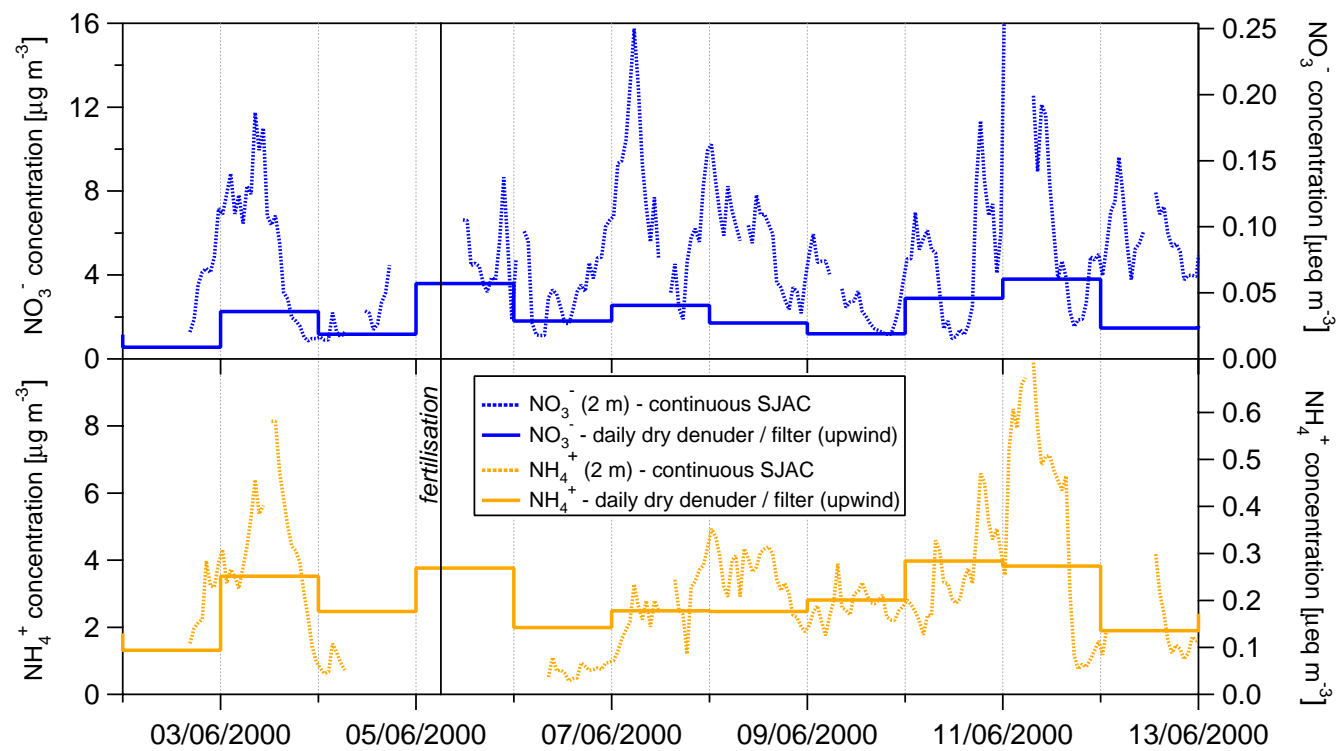

Fig. 3. Time-series of $\mathrm{NH}_{4}^{+}$and $\mathrm{NO}_{3}^{-}$aerosol concentration measured above and upwind of the grassland in both mass concentration and equivalent concentration. 


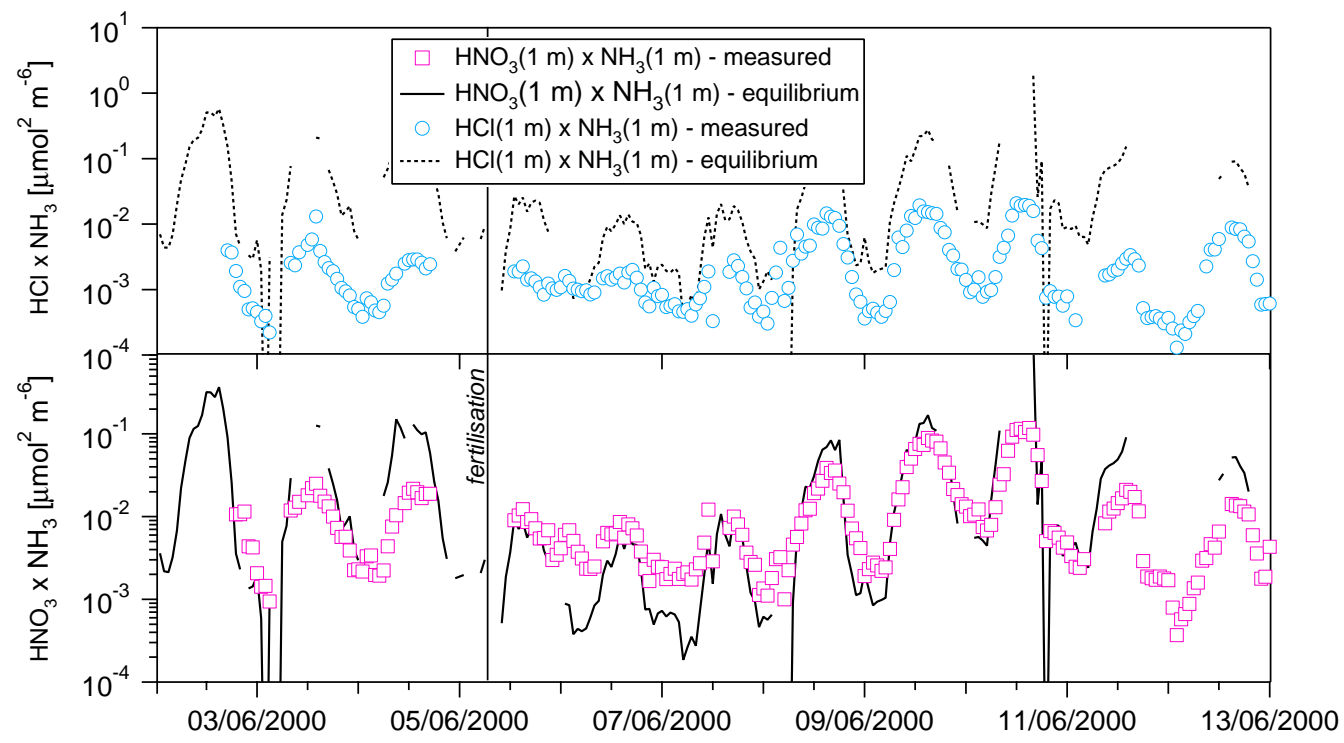

Fig. 4. Comparison of measured concentration products at $1 \mathrm{~m}$ height of (a) $\mathrm{NH}_{3}$ with $\mathrm{HNO}_{3}$ and (b) $\mathrm{NH}_{3}$ with $\mathrm{HCl}$, compared with concentration products in equilibrium with pure $\mathrm{NH}_{4} \mathrm{NO}_{3}$ and $\mathrm{NH}_{4} \mathrm{Cl}$ aerosol, respectively.

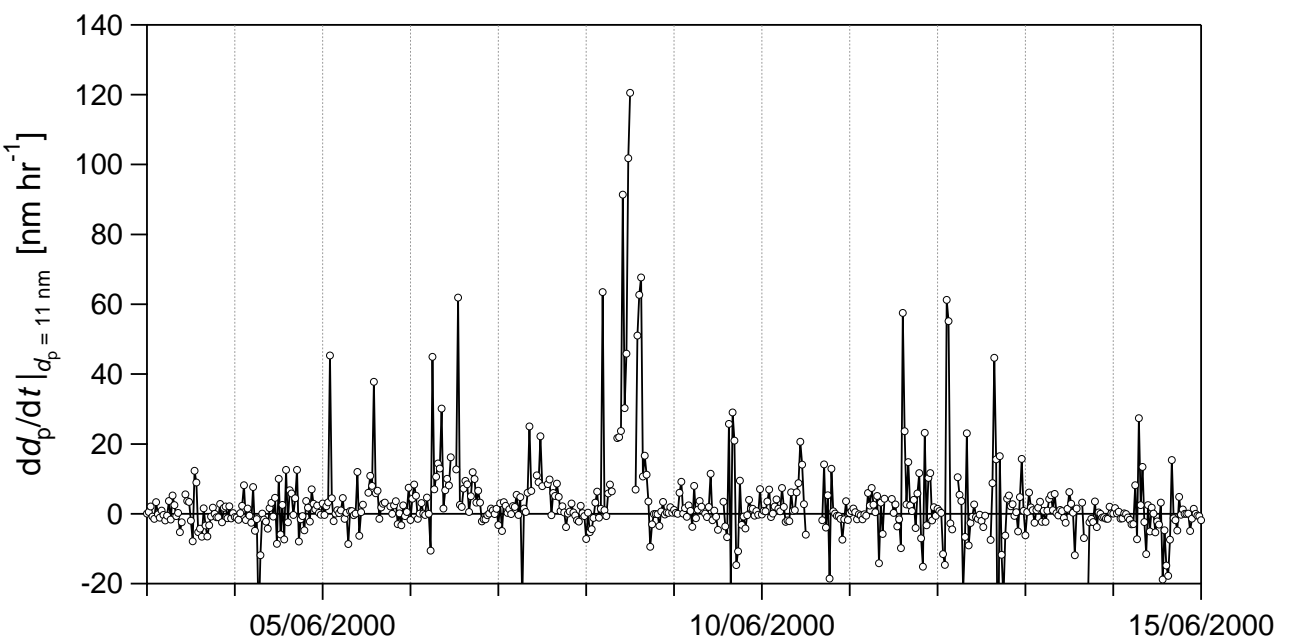

Fig. 5. Time-series of the growth rate of $11 \mathrm{~nm}$ particles $\left(\mathrm{d} d_{\mathrm{p}} / \mathrm{d} t\right)$ as derived from CPC flux measurements and DMPS measurements, using Eqs. (3), (4) and (5).

\subsection{Calculation of particle growth rates}

Growth rates of $11 \mathrm{~nm}$, total gas-to-particle conversion mass transfer fluxes, estimated vapour concentration and the effect of vapour condensation on the $\mathrm{NH}_{3}$ flux are presented in Fig. 5 and summarized in Table 3 as typical values for $12 \mathrm{~h}$ day and night-time periods following fertilizer application. They are compared with measurements of vapour concentrations and estimated total particle surface area.

\subsection{Effects on the measurements of ammonia flux}

Even if there is potential for the formation or evaporation of aerosol, the time-scale of this process may be too slow for surface exchange fluxes to be altered significantly. The chemical time-scale $\left(\tau_{\mathrm{c}}\right)$ (Wexler and Seinfeld, 1990) depends strongly on the surface area of the aerosol, while the turbulent time-scale $\left(\tau_{\mathrm{t}}\right)$ depends on the turbulence as characterised by the friction velocity $\left(u_{*}\right)$. Chemistry is thought to alter fluxes for Damköhler ratios $\left(D_{\mathrm{r}}=\tau_{\mathrm{t}} / \tau_{\mathrm{c}}\right)$ greater than 0.1 (Foken et al., 1995). Figure 6 demonstrates that this critical ratio is exceeded regularly, but only during night, when turbulent diffusive time scales are long, and the aerosol concentration (and hence surface area) is enhanced.

According to this time-scale analysis, major effects on the $\mathrm{NH}_{3}$ flux would be unlikely, at least during daytime. However, the observations presented here indicate that particle 
Table 3. Summary of typical particle growth parameters for various $12 \mathrm{~h}$ periods.

\begin{tabular}{|c|c|c|c|c|c|c|c|}
\hline Period & $\begin{array}{l}\text { Day/ } \\
\text { Night }\end{array}$ & $\begin{array}{r}F_{\mathrm{N}} \\
{\left[\mathrm{cm}^{-2} \mathrm{~s}^{-1}\right]}\end{array}$ & $\begin{array}{r}A_{\mathrm{p}} \\
{\left[\mu \mathrm{m}^{2} \mathrm{~m}^{-3}\right]}\end{array}$ & $\begin{array}{r}\mathrm{d} d_{\mathrm{p}} /\left.\mathrm{d} t\right|_{d_{\mathrm{p}}=11 \mathrm{~nm}} \\
{\left[\mathrm{~nm} \mathrm{hr}^{-1}\right]}\end{array}$ & $\begin{array}{r}J_{\mathrm{NH}_{4} \mathrm{NO}_{3}} \\
{\left[\mu \mathrm{g} \mathrm{m}^{-3} \mathrm{hr}^{-1}\right]}\end{array}$ & $\begin{array}{r}\Delta F_{\mathrm{NH}_{3}} \\
{\left[\mathrm{ng} \mathrm{m}^{-2} \mathrm{~s}^{-1}\right]}\end{array}$ & $\begin{array}{r}F_{\mathrm{NH}_{3}} \\
{\left[\mathrm{ng} \mathrm{m}^{-2} \mathrm{~s}^{-1}\right]}\end{array}$ \\
\hline 5-June & Day & 1789 & 293 & 4.36 & 0.95 & 0.112 & 597 \\
\hline 5/6-June & Night & 178 & 320 & 2.84 & 0.34 & 0.040 & 1262 \\
\hline 6-June & Day & 1102 & 115 & 11.46 & 0.79 & 0.094 & 887 \\
\hline 6/7-June & Night & 54 & 266 & 1.01 & 0.17 & 0.020 & 1001 \\
\hline 7-June & Day & 900 & 245 & 5.50 & 1.14 & 0.135 & 443 \\
\hline 7/8-June & Night & 230 & 297 & 2.46 & 0.47 & 0.055 & 1311 \\
\hline 8-June & Day & 1388 & 253 & 34.49 & 5.33 & 0.629 & 549 \\
\hline 8/9-June & Night & 293 & 245 & 1.10 & 0.26 & 0.031 & 193 \\
\hline 9-June & Day & 285 & 240 & 2.18 & 0.67 & 0.079 & 378 \\
\hline 9/10-June & Night & 149 & 401 & 1.42 & 0.46 & 0.054 & 862 \\
\hline 10-June & Day & 212 & 298 & 3.83 & 0.86 & 0.102 & 495 \\
\hline 10/11-June & Night & -30 & 556 & -0.04 & -0.08 & -0.009 & 160 \\
\hline 11-June & Day & 99 & 294 & 4.26 & 0.54 & 0.064 & 175 \\
\hline 11/12-June & Night & 114 & 327 & 6.26 & 2.01 & 0.237 & 168 \\
\hline 12-June & Day & -116 & 194 & -1.53 & -0.15 & -0.018 & 202 \\
\hline 12/13-June & Night & -6 & 320 & 1.18 & 0.43 & 0.051 & 98 \\
\hline 13-June & Day & 39 & 240 & -1.14 & -0.14 & -0.016 & 118 \\
\hline 13/14-June & Night & -129 & 333 & -0.24 & -0.10 & -0.012 & 99 \\
\hline Average & Day & 633 & 241 & 7.04 & 1.11 & 0.131 & 427 \\
\hline Average & Night & 95 & 341 & 1.78 & 0.44 & 0.052 & 573 \\
\hline
\end{tabular}

$F_{\mathrm{N}}$ : measured particle number flux; $A_{\mathrm{p}}$ : aerosol surface area per unit volume of air; $\mathrm{d} r /\left.\mathrm{d} t\right|_{d_{\mathrm{p}}=11 \mathrm{~nm}}$ : growth rate of $11 \mathrm{~nm}$ particles;

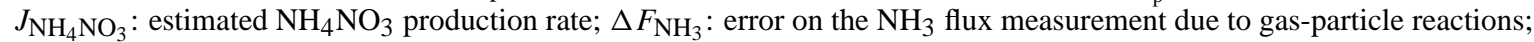

$F_{\mathrm{NH}_{3}}$ : measured $\mathrm{NH}_{3}$ flux.

growth was considerable, also during daytime. From the growth rate of $11 \mathrm{~nm}$ particles, the driving force for the condensation, the effective vapour concentration $\left(\chi_{\mathrm{V}}\right)$ was estimated using Eq. (4). And the total mass transfer from the gas

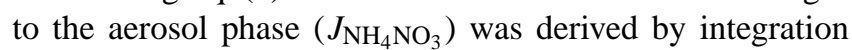
over the measured particle spectrum, using Eq. (9). From this mass transfer the error on the $\mathrm{NH}_{3}$ flux may be estimated. These parameters are also shown in Table 3, where they are also compared with the actual measured concentrations of $\mathrm{NH}_{3}$ and $\mathrm{HNO}_{3}$. The error on the $\mathrm{NH}_{3}$ flux measurement is small, on average $12.2 \mathrm{ng} \mathrm{m}^{-2} \mathrm{~s}^{-1}(1.5 \%)$ during day and $12.4 \mathrm{ng} \mathrm{m}^{-2} \mathrm{~s}^{-1}(6.6 \%)$ during night.

\section{Discussion}

\subsection{Deposition velocities to unfertilised grassland}

Dry deposition velocities of particles to vegetation have recently been reviewed by Pryor et al. (2008) and Petroff et al. (2008). At Braunschweig, particle number size distributions were dominated by particles in the size range 10 to $200 \mathrm{~nm}$ (Fig. 7) and thus the total particle number flux measurements were also dominated by this Aitken mode.

Particle deposition velocities are known to increase with increasing surface roughness, increasing $u_{*}$ and under unstable conditions (e.g. Wesley et al., 1985; Nemitz et al.,
2004). The measurement periods were insufficient long to derive robust relationships of $V_{\mathrm{d}}$ on these parameters from our measurements. However, values of $u_{*}$ were very similar between the different measurement periods and $H$ was similar during the later periods, but slightly reduced during the measurements above the long grass canopy, reflecting lower solar input (Table 1). In summary, the differences in deposition velocities are more likely linked to changes in surface roughness than meteorological differences. The mean $V_{\mathrm{d}}$ of $0.03 \mathrm{~mm} \mathrm{~s}^{-1}$ to cut $\left(h_{\mathrm{c}}=0.07 \mathrm{~m}\right), 0.06 \mathrm{~mm} \mathrm{~s}^{-1}$ to partly regrown $\left(h_{\mathrm{c}}=0.12 \mathrm{~m}\right)$ and $0.26 \mathrm{~mm} \mathrm{~s}^{-1}$ to tall $\left(h_{\mathrm{c}}=0.75 \mathrm{~m}\right)$ grassland measured at the Braunschweig field site appears to be at the low end of measurements reported in the literature, but only few studies have measured total number fluxes over short vegetation. Nemitz et al. (2002) reported a mean deposition velocity of $0.3 \mathrm{~mm} \mathrm{~s}^{-1}$ to Scottish moorland vegetation $\left(h_{\mathrm{c}}=0.06 \mathrm{~m}\right)$, measured with a similar setup; the difference is only partly explained by higher wind speeds during the UK measurements with an average $u_{*}$ of $0.25 \mathrm{~m} \mathrm{~s}^{-1}$ compared with $0.18 \mathrm{~m} \mathrm{~s}^{-1}$ during the present study. Lamaud et al. (1994) measured average $V_{\mathrm{d}}$ of $0.7 \mathrm{~mm} \mathrm{~s}^{-1}$ to semi arid savannah, using an instrument that measured total particle flux, but weighted by surface area. Thus, their measurement is biased towards larger particle than the measurements made here. 


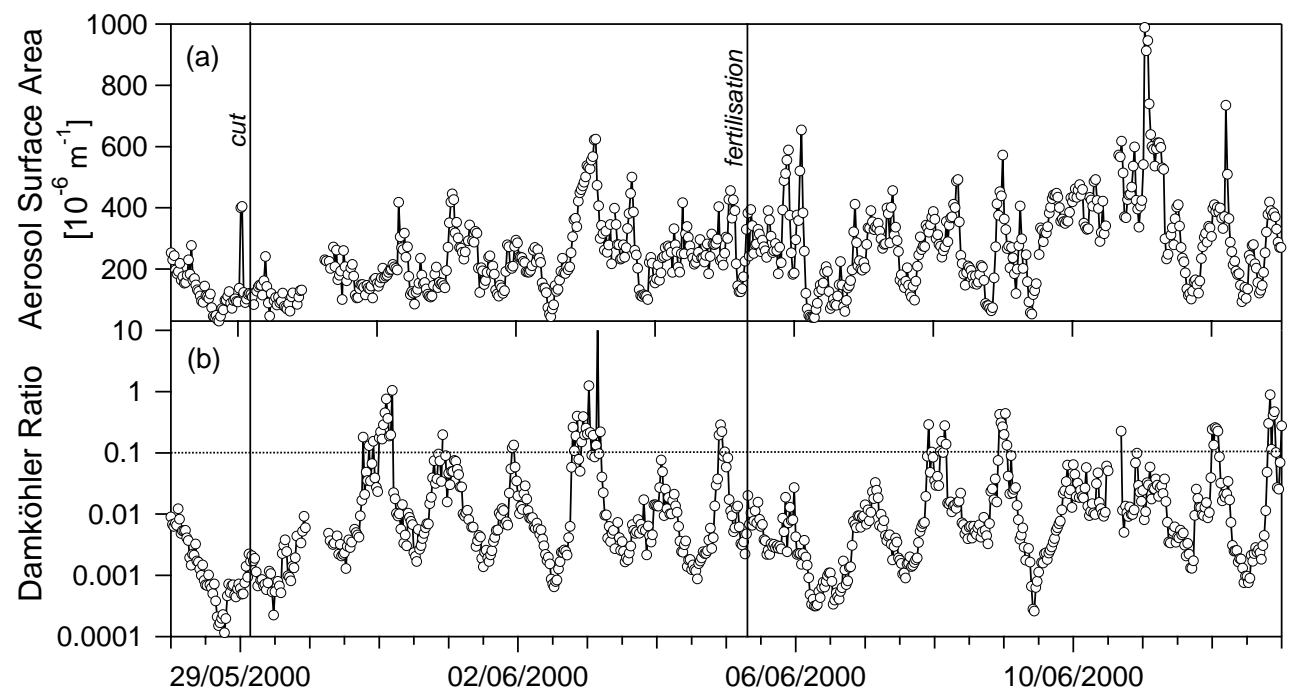

Fig. 6. Time-series of the aerosol surface area and the Damköhler ratio $\left(D_{\mathrm{r}}=\tau_{\mathrm{t}} / \tau_{\mathrm{c}}\right)$. The dashed line represents the critical value of $D_{\mathrm{r}}$, above which chemistry is expected to alter the vertical gradients.

Other studies above short vegetation have focused on accumulation mode particles $(0.1-0.5 \mu \mathrm{m})$ that can be sized with optical techniques (Nemitz et al., 2002; Vong et al., 2004) or mass fluxes, also dominated by the accumulation mode (Wesely et al., 1985): Vong et al. (2004) derived particle deposition velocities to grassland $\left(0.75 \mathrm{~m}<h_{\mathrm{c}}<1 \mathrm{~m}\right)$ as a function of particle size and stability. Values of $V_{\mathrm{d}}$ for the smallest size $\left(d_{\mathrm{p}}=0.34 \mu \mathrm{m}\right)$ ranged from 2 during stable to $6 \mathrm{~mm} \mathrm{~s}^{-1}$ during unstable conditions, while values of $V_{\mathrm{d}}$ for larger particles $\left(d_{\mathrm{p}}=0.84 \mu \mathrm{m}\right)$ increased from 2 to $7 \mathrm{~mm} \mathrm{~s}^{-1}$. At the Scottish moorland site, $V_{\mathrm{d}}$ of accumulation mode particles ranged from $0.3 \mathrm{~mm} \mathrm{~s}^{-1}\left(d_{\mathrm{p}}=0.1 \mu \mathrm{m}\right)$, over $2 \mathrm{~mm} \mathrm{~s}^{-1}(0.5 \mu \mathrm{m})$ to $>10 \mathrm{~mm} \mathrm{~s}^{-1}(3 \mu \mathrm{m})$. Similarly, Wesely et al. (1985) derived an average $V_{\mathrm{d}}$ of $2.2 \mathrm{~mm} \mathrm{~s}^{-1}$ for $\mathrm{SO}_{4}^{2-}$ deposition to grassland, with a likely mass median diameter of $0.4 \mu \mathrm{m}$.

Dorsey (2002) and Gallagher et al. (2002) also presented measurements of size-segregated particle fluxes made at the Braunschweig field site, deriving average $V_{\mathrm{d}}$ for particles with $0.1 \mu \mathrm{m}<d_{\mathrm{p}}<0.2 \mu \mathrm{m}$ of $0.87 \mathrm{~mm} \mathrm{~s}^{-1}$ for the cut and $1.13 \mathrm{~mm} \mathrm{~s}^{-1}$ for the long grass. It is thus likely that the relative low deposition velocity of total particle flux is strongly biased by inefficient deposition of particles $<0.1 \mu \mathrm{m}$. While the deposition velocities presented here are therefore representative for primary organic aerosol components much of which are found in the Aitken mode, they are probably underestimations for the average deposition of secondary aerosol constituents, which occupies the accumulation mode (e.g., Allan et al., 2003).

No correction was made here for frequency losses due to the limitation of the CPC. From co-spectral analysis it was estimated that the average flux (and thus $V_{\mathrm{d}}$ ) may be underestimated by up to $30 \%$ (Dorsey, 2002).

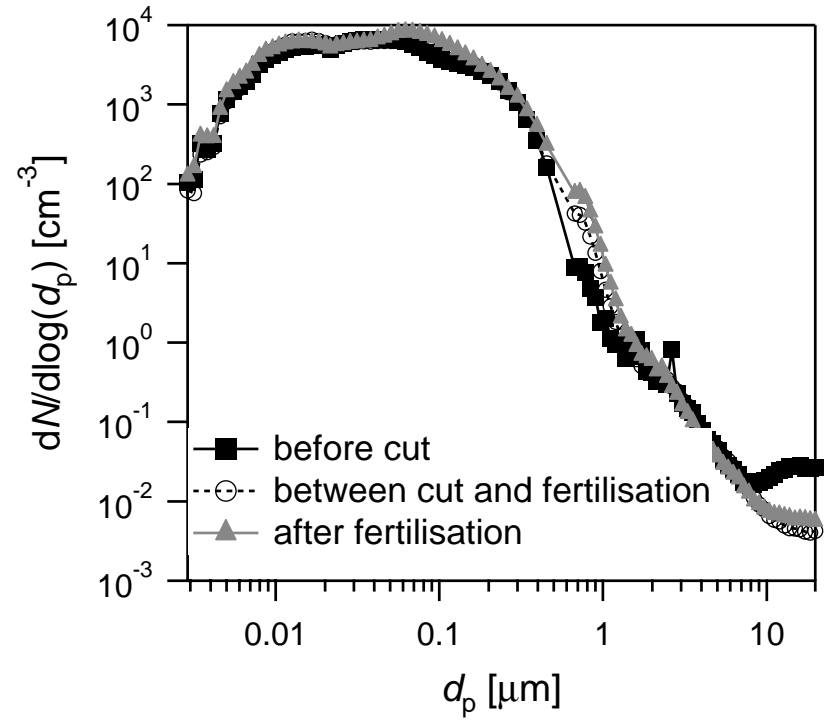

Fig. 7. Averaged particle size-distributions during the three management periods.

\subsection{Assessment of alternative mechanism causing ap- parent particle emission fluxes following fertilisa- tion}

The analysis presented so far has implied that the particle emission fluxes were due to combined $\mathrm{NH}_{3}$ and $\mathrm{HNO}_{3}$ condensation. We here consider alternative mechanisms.

Biogenic VOC emissions of leaf alcohols and breakdown products, but also of effective precursor gases such as alkenes, have been reported to increase dramatically immediately after grass cutting (Kirstine et al., 1998; Karl et al., 


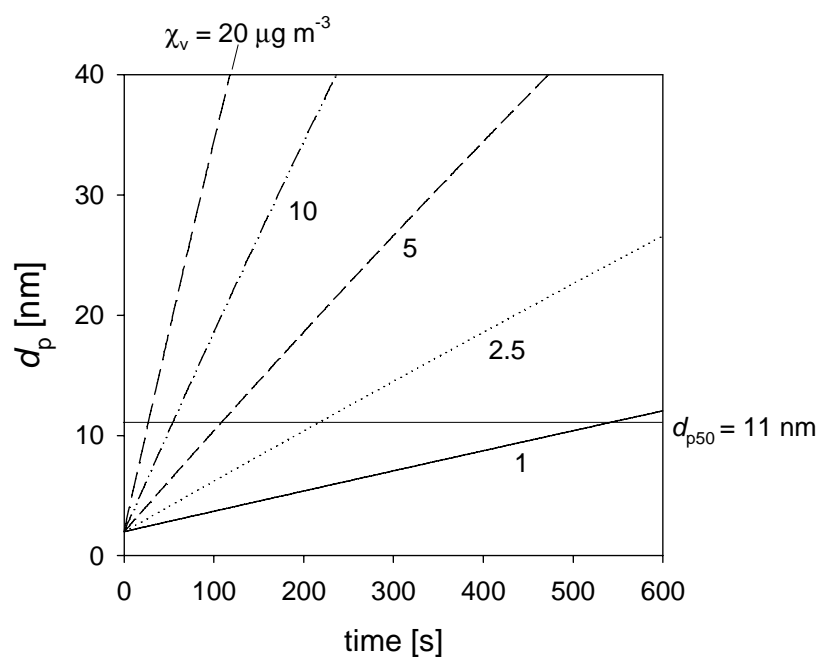

Fig. 8. Time-evolution of the size of particles, with an initial diameter $\left(d_{\mathrm{p}}\right)$ of $2 \mathrm{~nm}$, for a range of vapour concentrations $\left(\chi_{\mathrm{V}}\right)$.

2001). Although some particle emissions were observed at the GRAMINAE experiment after grass cutting, these can be related to agricultural activities on the field (e.g. turning), while persistent apparent particle emissions occurred only after fertilization. The limited number of measurements of BVOC concentrations and, though less certain, their fluxes do not indicate that fertilization had an influence on VOCs. Non-zero water vapour fluxes can also cause artifacts for size-dependent particle flux measurements (Kowalski, 2001), but this effect would also have been similar before and after fertilization: the average latent heat flux during the week before fertilization of $49 \mathrm{~W} \mathrm{~m}^{-2}$ was very similar to the average latent heat flux during the first five days after fertilization $\left(52 \mathrm{~W} \mathrm{~m}^{-2}\right)$ (Nemitz et al., 2009a).

The only major change induced by the fertilization was a greatly increased emission of $\mathrm{NH}_{3}$ (Fig. 2c), resulting in enhanced concentrations both at the canopy height $\left(z_{0}{ }^{\prime}\right)$ and the average measurement height of $1 \mathrm{~m}$ (Fig. 2b), indicating that the change in $\mathrm{NH}_{3}$ is almost certainly the cause for the observed apparent particle emissions. Having established the role of $\mathrm{NH}_{3}$ as a precursor, the particle emission fluxes may still be linked to one of three processes: (i) ternary nucleation of the $\mathrm{H}_{2} \mathrm{O}-\mathrm{H}_{2} \mathrm{SO}_{4}-\mathrm{NH}_{3}$ system, followed by growth across the $11 \mathrm{~nm}$ threshold, (ii) nucleation of new $\mathrm{NH}_{4} \mathrm{NO}_{3}$ or $\mathrm{NH}_{4} \mathrm{Cl}$ particles, followed by growth across the $11 \mathrm{~nm}$ threshold and (iii) particle growth due to the combined condensation of $\mathrm{NH}_{3}$ and $\mathrm{HNO}_{3}$ or $\mathrm{NH}_{3}$ and $\mathrm{HCl}$ on the surface of existing particles. It is highly improbable, however, that particle nucleation, i.e. processes (i) or (ii), played a role in the observed apparent emission fluxes, for several reasons:

(a) Binary nucleation of volatile compounds such as $\mathrm{NH}_{4} \mathrm{NO}_{3}$ and $\mathrm{NH}_{4} \mathrm{Cl}$ is inefficient under ambient conditions (e.g., Korhonen et al., 1997). (b) Ternary nucleation of the $\mathrm{H}_{2} \mathrm{O}-\mathrm{H}_{2} \mathrm{SO}_{4}-\mathrm{NH}_{3}$ system can be important, where $\mathrm{H}_{2} \mathrm{SO}_{4}$ concentrations are large and competing condensational sinks are small (due to low aerosol loading). However, only small $\mathrm{NH}_{3}$ concentrations in the $\mathrm{ng} \mathrm{m}^{-3}$ range, virtually always present in agricultural areas, are necessary to promote ternary nucleation of the $\mathrm{H}_{2} \mathrm{O}-\mathrm{H}_{2} \mathrm{SO}_{4}-\mathrm{NH}_{3}$ system significantly, while the nucleation rate is insensitive to further increases in $\mathrm{NH}_{3}$ concentrations beyond $100 \mathrm{ppt}$ $\left(\sim 76 \mathrm{ng} \mathrm{m}^{-3}\right)$ (e.g. Napari et al., 2002). Therefore, the enhanced $\mathrm{NH}_{3}$ emission after fertilization would not have greatly changed the efficiency of this particle production mechanism.

(c) Although individual nucleation events were observed at the measurement site (Sutton et al., 2008a), there was no difference in the average size distribution of the DMPS measurements before and after fertilisation, and average size distributions did not show a clear nucleation mode (Fig. 7). This suggests that the observed nucleation events were regional in nature and independent of local $\mathrm{NH}_{3}$ emissions.

(d) To estimate whether growth of newly nucleated particles, at a diameter of typically $2 \mathrm{~nm}$, would have been sufficiently quick to be detected by the CPC, Eq. (6) can be used to simulate the growth of $2 \mathrm{~nm}$ particles at different vapour concentrations. The results (Fig. 8) demonstrate that it takes almost an hour for a $2 \mathrm{~nm}$ particle to become detectable, even at $\chi_{\mathrm{v}}=50 \mu \mathrm{g} \mathrm{m}^{-3}$. For comparison, at typical wind speeds of $4 \mathrm{~m} \mathrm{~s}^{-1}$ and an extent of the grassland of between 150 and $500 \mathrm{~m}$, depending on wind direction, the residence time above the field is of the order of 1 to $5 \mathrm{~min}$.

In summary, it is highly unlikely that particle nucleation was involved in causing the observed upward fluxes. Instead, the observation of emission fluxes was almost certainly due to condensation particle growth of particles across the $11 \mathrm{~nm}$ cut-off size of the CPC.

\subsection{Proposed mechanism leading to apparent particle emission fluxes}

After fertilization, close agreement was found between measured concentration products of $\left[\mathrm{NH}_{3}\right] \times\left[\mathrm{HNO}_{3}\right]$ at $1 \mathrm{~m}$ and those predicted to be in equilibrium with $\mathrm{NH}_{4} \mathrm{NO}_{3}$. For $\mathrm{NH}_{4} \mathrm{Cl} K_{\mathrm{m}}<<K_{\mathrm{e}}$ was always observed, eliminating $\mathrm{HCl}$ and supporting $\mathrm{HNO}_{3}$ as a potential associated precursor. According to the process understanding emerging from the Braunschweig experiment work, direct $\mathrm{NH}_{3}$ evaporation of fertilizer pellets would have dominated the measured emissions (Fig. 2c) directly after fertilizer application, until there was a significant amount of precipitation (Sutton et al., 2008b). Precipitation of $2.6 \mathrm{~mm}$ was recorded for the evening of 5 June and $1.3 \mathrm{~mm}$ during the late morning of the 7 th. 


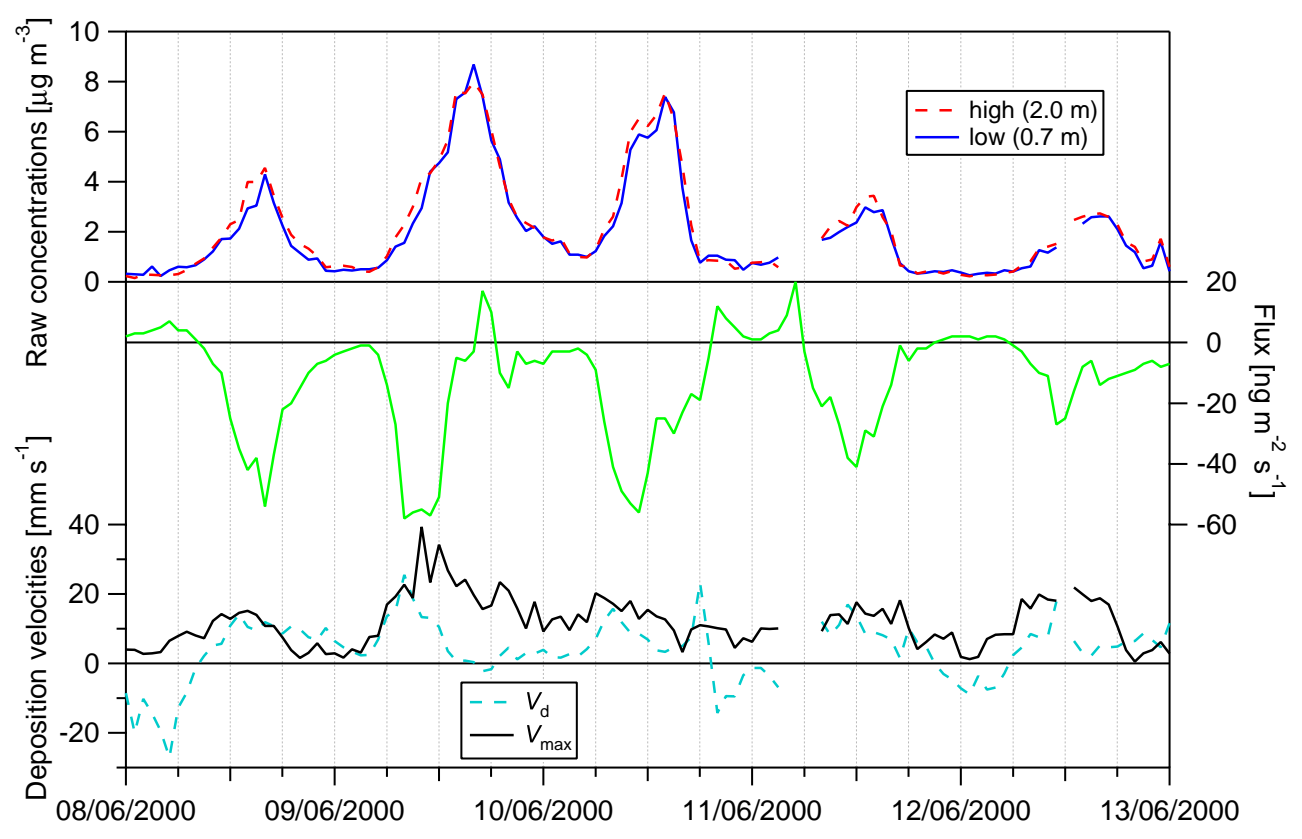

Fig. 9. Concentration, flux and deposition velocity of $\mathrm{HNO}_{3}$ measured with the SJAC/WAD gradient system, in relation to the maximum deposition velocity $\left(V_{\max }\right)$.

From 6 or 7 June $\mathrm{NH}_{3}$ emission was probably dominated by the enhanced $\mathrm{NH}_{4}^{+}$concentration in soil solution and leaf litter, evident in the measurements, and the gradually increasing emission potential of the plants (Riedo et al., 2002; Sutton et al., 2009b). Small night-time emissions suggest that non-stomatal emissions, such as soil emissions, still contributed to the flux even 5 days after fertilization. Leaflitter on the soil surface represents and additional $\mathrm{NH}_{3}$ source which would have been re-captured in the tall canopy, but is able to escape the canopy after the cut (David et al., 2008; Sutton et al., 2009b).

Because of their solubility in water, the acid gases $\mathrm{HNO}_{3}$ and $\mathrm{HCl}$ are conventionally expected to deposit at the maximum rate permitted by turbulence $\left(V_{\max }\right)$.

$V_{\text {max }}=\left(R_{\mathrm{a}}(z-d)+R_{\mathrm{b}}\right)^{-1}$,

where $R_{\mathrm{a}}(z-d)$ is the aerodynamic resistance which is a function of height $(\mathrm{z})$ above zero-plane displacement height (d), and $R_{\mathrm{b}}$ is the quasi-laminar sublayer resistance, which is dependent on the molecular diffusivity of the gas under investigation. Both resistances can be calculated from measured micrometeorological parameters (Nemitz et al., 2009a). A reduction in the deposition velocity of acid gases indicates sources or non-zero equilibrium concentrations at or near the ground. Nemitz et al. (2004) showed that reduced $\mathrm{HNO}_{3}$ deposition at a Dutch heathland was consistent with evaporation of airborne $\mathrm{NH}_{4} \mathrm{NO}_{3}$ due to small precursor gas concentration products near the ground. Nemitz et al. (2000) reported emissions of $\mathrm{HCl}$ and Neftel et al. (1996) reported upward gradients of $\mathrm{HNO}_{3}$, both of which they explained by leaf surface chemistry.
Although not without uncertainty, the $\mathrm{HNO}_{3}$ gradient measurements at Braunschweig showed reduced deposition velocities $\left(V_{\mathrm{d}}<V_{\max }\right)$ during the afternoons of some of the days after fertilisation (e.g. 9 June) (Fig. 9). The reduced deposition velocities of $\mathrm{HNO}_{3}$ suggest that at least some of the $\mathrm{HNO}_{3}$ is also surface-derived, with fertiliser pellets and high soil $\mathrm{NO}_{3}^{-}$concentrations resulting in a non-zero gas-phase concentration at the ground, at least during warm afternoons. $\mathrm{HNO}_{3}$ concentrations exhibited a clear diurnal cycle with the maximum concentrations during the day (Figs. 2a and 8), which would be consistent with either its production from $\mathrm{NO}_{\mathrm{x}}$, or the cycle in the equilibrium constant of $\mathrm{NH}_{4} \mathrm{NO}_{3}$ (Fig. 4).

In general, $K_{\mathrm{m}}$ and $K_{\mathrm{e}}$ change with height, in response to gradients of vapour concentrations, $T$ and $h$ : the increase of $\mathrm{NH}_{3}$ and $h$ towards the ground increase $K_{\mathrm{m}}$ relative to $K_{\mathrm{e}}$, while the decrease in $\mathrm{HNO}_{3}$ and increase of $T$ would have the opposite effect. Unexpected particle fluxes have been attributed to the formation or evaporation of $\mathrm{NH}_{4}^{+}$before: van Oss et al. (1998) simulated over-rapid deposition of $\mathrm{NO}_{3}^{-}$ aerosol to forest to aerosol evaporation. Nemitz et al. (2004) reported fast deposition of $\mathrm{NH}_{4}^{+}$by gradient technique to a Dutch heathland, while eddy-correlation particle fluxes appeared to detect deposition of particles $>0.2 \mu \mathrm{m}$ at the same time as emission of smaller particles. In a modelling study, Nemitz and Sutton (2004) demonstrated that both observations are consistent with the evaporation of $\mathrm{NH}_{4} \mathrm{NO}_{3}$ during the deposition process, caused by the depletion of $\mathrm{NH}_{3}$ and $\mathrm{HNO}_{3}$ close to the ground. 


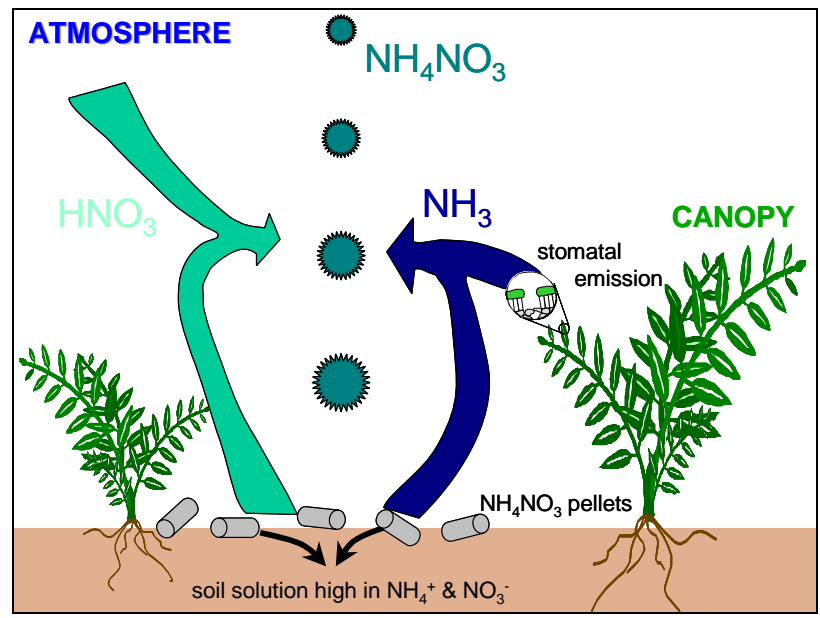

Fig. 10. Schematic of the proposed processes of emission, gasparticle conversion and deposition at the fertilised grassland site.

In summary, the following picture emerges: a combination of $\mathrm{NH}_{4}^{+}$enriched soil, litter and leaf solutions combined with initial losses directly from the fertilizer pellets leads to emission of $\mathrm{NH}_{3}$ which partly re-condenses on the surface of atmospheric aerosol particles above the ground, where, at least during the day, temperatures are lower. This condensation of $\mathrm{NH}_{3}$ is likely to be associated with simultaneous condensation of $\mathrm{HNO}_{3}$, which may be partly derived from the atmosphere or from fertilizer volatilization. It is likely that atmospheric $\mathrm{HNO}_{3}$ was the main source during night, when the potential for $\mathrm{HNO}_{3}$ emission from the ground was lower. This condensation results in the particles growing during the deposition process (Fig. 10), causing a deposition gradient in the total particle number, but an apparent increase of particles with $d_{\mathrm{p}}>11 \mathrm{~nm}$, which is detected as an apparent particle emission flux.

\subsection{Time-scales of particle growth}

Particle nucleation and growth due to condensation are ubiquitous across the world, with the exception of the tropics, with typical growth rates in the region of $1-20 \mathrm{~nm} \mathrm{hr}^{-1}$ (Kulmala et al., 2004; Holmes, 2007) and can be attributed to a range of precursors. For example, Verheggen et al. (2000) derived growth rates due to $\mathrm{H}_{2} \mathrm{SO}_{4}$ condensation of 3 to $7 \mathrm{~nm} \mathrm{hr}^{-1}$ from size-distribution measurements. Growth rates of 2 to $11 \mathrm{~nm} \mathrm{hr}^{-1}$ were observed following nucleation events during the BIOFOR campaigns above Finish forests, attributed to the condensation of BVOCs, while faster growth rates of 15 to $180 \mathrm{~nm} \mathrm{hr}^{-1}$ have been derived in the maritime environment during PARFORCE, possibly due to the uptake of biogenic methylated iodine species (Dal Maso et al., 2002). Growth rates linked to the emission of agricultural precursors do not appear to have been presented in the literature. A likely reason is that, until now, most growth rates
Table 4. Effects of gas-to-particle conversion on flux measurements and budget estimates of reactive nitrogen (excluding $\mathrm{NO}_{\mathrm{x}}$ ). Fluxes are in $\mathrm{kg} \mathrm{Nha}^{-1}$ for the period 5 to 15 June 2000; negative values represent deposition fluxes.

\begin{tabular}{lrrr}
\hline Component & $\begin{array}{r}\text { Measurements, and } \\
\text { parameterisations not } \\
\text { corrected for chemistry }\end{array}$ & $\begin{array}{r}\text { Corrected best } \\
\text { estimate for } \\
\text { surface }\end{array}$ & $\begin{array}{r}\text { No chemistry } \\
\text { scenario }\end{array}$ \\
\hline $\mathrm{NH}_{3}$ gas & 3.22 & 3.27 & $<3.27^{\mathrm{a}}$ \\
$\mathrm{HNO}_{3}$ gas & -0.043 & 0.011 & $-0.033^{\mathrm{b}}$ \\
$\mathrm{NH}_{4}^{+}$aerosol & -0.028 & -0.083 & $-0.027^{\mathrm{b}}$ \\
$\mathrm{NO}_{3}^{-}$aerosol & -0.010 & -0.065 & $-0.007^{\mathrm{b}}$ \\
\hline Net N flux & 3.14 & 3.13 & $<3.20$ \\
\hline
\end{tabular}

(a) Emission would be reduced due to larger air concentration (cf text). (b) Estimated from KAPS filter/denuder measurements over adjacent field.

have been derived by analysis of the time-evolution of sizedistributions, typically following nucleation events or emission plumes - an approach, which requires these processes to occur at the regional scale. By contrast, agricultural activity such as fertilisation happens at the field scale. Here we have developed and applied a new approach to derive growth rates at the field scale, through a combination of measurements of particle flux and aerosol size distribution.

The growth rates derived in this study for combined $\mathrm{NH}_{3}$ $\mathrm{HNO}_{3}$ uptake (Table 3) are in the range of these previous studies, with $11 \mathrm{~nm}$ particles growing at about $7.04 \mathrm{~nm} \mathrm{hr}^{-1}$ during the day and $1.78 \mathrm{~nm} \mathrm{hr}^{-1}$ at night, with maxima of 40 to $60 \mathrm{~nm} \mathrm{hr}^{-1}$ (Fig. 5). In order to compare growth rates between studies, it is important to note that the growth rate is size-dependent. For large particles, condensation increases with the surface area $\left(\propto d_{\mathrm{p}}^{2}\right)$, while the growth decreases with volume $\left(\propto d_{\mathrm{p}}^{-3}\right)$, resulting in an overall $d_{\mathrm{p}}^{-1}$ proportionality. For particles in the transition regime, mass transfer limitations further reduce the growth rate. Growth rates adjusted for $d_{\mathrm{p}}=200 \mathrm{~nm}$ averaged $0.35 \mathrm{~nm} \mathrm{hr}^{-1}$ during the day and $0.09 \mathrm{~nm} \mathrm{hr}^{-1}$ during night (Table 2).

It should be noted that other particle dynamic processes, in particular coagulation, are not considered in the approach presented here (Eq. 5). Since no particular nucleation mode was observed during this study, new particle formation is not considered to be and important process here. This is in contrast to studies were growth rates are derived from the evolution of size-distributions following nucleation events. At the Braunschweig field site, size-distributions were similar before and after fertilization (Fig. 7) and thus coagulation would also have affected fluxes similarly. Furthermore there is no reason to believe that coagulation would have acted differently above and below the measurement height. Thus, in the interpretation of CPC flux measurements, coagulation is not normally considered. It would indeed be interesting to estimate the effect of coagulation on particle fluxes, which 
does not appear to have been done before, but which is beyond this study

The approach developed here, to derive growth rates at the field scale from the combined measurement of particle flux and size distribution is sufficiently sensitive to detect growth rates of a few $\mathrm{nm} \mathrm{hr}^{-1}$. The main uncertainty relates to the estimate of the dry deposition flux at the surface and thus to the variability in the dry deposition velocity, which is here assumed to be constant with time $\left(0.06 \mathrm{~mm} \mathrm{~s}^{-1}\right)$. Under the conditions encountered here, an increase of $V_{\mathrm{d}}$ to $1 \mathrm{~mm} \mathrm{~s}^{-1}$ translates into an increase in the estimated growth rate by about $3 \mathrm{~nm} \mathrm{hr}^{-1}$. From the range of results found in the other studies cited above, it appears that the potential range of deposition velocities lies within the range 0 to $2 \mathrm{~mm} \mathrm{~s}^{-1}$ for the size-range 11 to $200 \mathrm{~nm}$, which dominated the number sizedistribution that would have been detected during the experiment presented here. It follows that the error range in the growth rate lies between -0.18 to $+6 \mathrm{~mm} \mathrm{hr}^{-1}$. In addition, the potential underestimation of the flux due to the limited frequency response of the particle counter, would have resulted in under-estimation of both the $V_{\mathrm{d}}$ to the unfertilized grassland and apparent emission fluxes above the fertilized grassland. Thus, the growth rates derived here appear to be conservative and are more likely an under- than an overestimate.

The time-scale analysis (Fig. 6) indicates that chemistry should only be relevant during night-time conditions, while apparent emission fluxes were also observed during daytime. This highlights the limitations of the time-scale analysis based on Damköhler ratios. The analysis here is based on the above-canopy turbulent time-scale. Although chemistry may not be efficient well above the canopy, in the region for which the turbulence time-scale $\tau_{\mathrm{t}}$ was estimated, obviously a region exists where $\tau_{\mathrm{t}}$ becomes comparable to $\tau_{c}$. Indeed, radon tracer measurements showed that the timescale for diffusion out of the grass canopy is long (Nemitz et al., 2009b). Thus all relevant time-scales need to be considered when assessing the overall potential for chemistry to modify fluxes between the point of emission and measurement.

\subsection{Implications for flux measurements and local bud- gets of nitrogen}

There are three ways in which gas-particle conversion affects fluxes and local budgets, which are assessed in this section.

(a) Error for flux measurement. As the vertical gradient is modified by the chemistry, the aerodynamic gradient technique (AGM) may need to be modified to derive the correct flux. Similarly, the flux measured by micrometeorological techniques that operate at a single measurement height $\left(z_{\mathrm{m}}\right)$, such as EC and REA, differs from the true surface exchange. (b) Error for inferential estimates and deposition modelling. Deposition and emission are often derived from the air concentration in an inferential approach, using resistance models of a range of complexity. This approach does not usually consider chemical conversion within the resistance analogue. In addition, changes in the gas/particle partitioning modify air concentrations compared with the simulation of an atmospheric transport model that ignores chemical reactions. For example, the $\mathrm{NH}_{3}$ air concentration is lowered by transfer to the particle phase, further stimulating stomatal emission, which is governed by the difference between stomatal compensation point and atmospheric concentration.

(c) Modification of the local $N$ budget. A fraction of the emitted $\mathrm{NH}_{3}$ is converted into slowly depositing $\mathrm{NH}_{4} \mathrm{NO}_{3}$ aerosol, "increasing" the potential for deposition. Similarly, fast depositing $\mathrm{HNO}_{3}$ is converted into slowly depositing $\mathrm{NH}_{4} \mathrm{NO}_{3}$ aerosol, "decreasing" this deposition. The net effect of gas-to-particle conversion on the local $\mathrm{N}$ budget will depend on the relative magnitudes of the different compounds involved.

The average $\mathrm{NH}_{4} \mathrm{NO}_{3}$ production rate below the measurement height of the CPC fluxes was estimated to be 1.11 and $0.44 \mu \mathrm{g} \mathrm{m}^{-3} \mathrm{~h}^{-1}$ for day- and night-time, respectively. If it is assumed (a) that production above this measurement height is negligible as ammonia concentrations decline with increasing height and (b) that the particle production would have lasted for 14 days after fertilization, then this would equate to a production rate of $5.2 \mathrm{~g} \mathrm{NH}_{4} \mathrm{NO}_{3} \mathrm{ha}^{-1}$ or $0.0017 \%$ of the fertilizer $\mathrm{N}$ applied. By comparison, $3.2 \%$ of the fertilizer $\mathrm{N}$ were estimated to be emitted as $\mathrm{NH}_{3}$, either by direct volatilisation or, later on, by raising the stomatal compensation point within the first 10 days of fertilisation (Milford et al., 2008), i.e., around $0.05 \%$ of the emitted ammonia was converted to ammonium aerosol within the first $2 \mathrm{~m}$ above the ground.

Table 4 compares three estimates of the fluxes of the different reactive nitrogen species. The first one is based on the measurements above the field itself. The second estimate summarises the best estimate of the true surface exchange, correcting for the chemical interaction. The final estimate represents the fluxes that would be expected with an inferential modeling approach, if atmospheric concentrations were not influenced by the chemistry above the field. This is based on the concentrations measured at the background field. The $\mathrm{NH}_{3}$ emission from the field would be expected to be somewhat suppressed in this scenario as the $\mathrm{NH}_{3}$ concentration above the field would be slightly larger, but the exact $\mathrm{NH}_{3}$ emission under these modified conditions is difficult to estimate. Because at this site the total $\mathrm{N}$ flux is very much dominated by $\mathrm{NH}_{3}$, and the relative effect on the $\mathrm{NH}_{3}$ flux is small, the difference for the total $\mathrm{N}$ flux is small above this particular field. However, the flux on the other forms of $\mathrm{N}$ 
is considerable and even can lead to flux reversal, suggesting that in other circumstances these interactions could have larger relative effects on local nitrogen budgets.

\subsection{Implication for global budgets and climate forcing}

From fertiliser consumption statistics it is estimated that $4.5 \mathrm{Mt}$ of $\mathrm{NH}_{4} \mathrm{NO}_{3}-\mathrm{N}$ are used in Europe every year and 12.3 Mt globally (Matthews, 1994). Extrapolation of our measurements to the globe implies global $\mathrm{NH}_{4} \mathrm{NO}_{3}-\mathrm{N}$ formation/emissions following fertilizer application of $0.21 \mathrm{kt}$. Again this estimate is based on the assumption that $\mathrm{NH}_{4} \mathrm{NO}_{3}$ formation is confined to the bottom $2 \mathrm{~m}$, above which precursor gas concentrations are estimated to be sufficiently diluted for continued aerosol formation. Volatilisation of $\mathrm{NH}_{4} \mathrm{NO}_{3}$ fertiliser contributes only $0.46 \%$ to the global $\mathrm{NH}_{3}$ emissions (Bouwman et al., 1997), with the main part of the emissions arising from animal wastes and organic fertilizers; and hence the overall $\mathrm{NH}_{4} \mathrm{NO}_{3}-\mathrm{N}$ formation following $\mathrm{NH}_{3}$ emissions could easily be as large as $45 \mathrm{kt} \mathrm{NH}_{4} \mathrm{NO}_{3}-\mathrm{N}$. This reaction will depend on background concentrations of $\mathrm{HNO}_{3}$, competition with reaction with sulphur and meteorology. It should also be noted that, unlike with ammonium sulphates, any $\mathrm{NH}_{4} \mathrm{NO}_{3}$ formed has the potential to re-evaporate if the gas phase concentrations of $\mathrm{NH}_{3}$ and $\mathrm{HNO}_{3}$ drop below the equilibrium values. For comparison, the global ammonium sulphate formation is estimated to be in the order of $57 \mathrm{Mt} \mathrm{S} \mathrm{yr}^{-1}$ (IPCC, 2001).

\section{Conclusions}

Average deposition velocities to (unfertilised) cut, partially regrown and tall grassland were $0.03,0.06$ and $0.24 \mathrm{~mm} \mathrm{~s}^{-1}$, respectively. This is at the lower end of values reported for short vegetation, but consistent with the number flux being dominated by Aitken mode particles. The values are therefore applicable, e.g., to derive deposition of combustion derived primary aerosol. Analysis of sustained apparent emission fluxes after fertilisation, in relation to potential pre-cursor gases shows that these are consistent with condensation of $\mathrm{NH}_{3}$ and $\mathrm{HNO}_{3}$ and associated growth across the $11 \mathrm{~nm}$ diameter cut-off of the particle counter used for the flux measurements.

We have here developed a novel technique to derive particle growth rates from flux measurements using instruments with well-defined cut-off diameters, together with measurements of the size-distribution. Former estimates of growth rates have usually relied on the presence of a clear nucleation mode, whose size evolution could easily be monitored. By contrast our new approach is universally applicable to derive particle growth rates over homogeneous surfaces at the field scale and could, for example, be used to derive aerosol growth rates due to biogenic secondary organic aerosol formation in natural environments, where bi-directional particle number fluxes are observed, even if this growth happens over a limited area.

Above the fertilized field growth rates of $11 \mathrm{~nm}$ particles of $7.0 \mathrm{~nm} \mathrm{hr}^{-1}$ during the day and $1.78 \mathrm{~nm} \mathrm{hr}^{-1}$ at night are similar to those reported in the literature for the uptake of organic vapours and $\mathrm{H}_{2} \mathrm{SO}_{4}$, and illustrate the efficiency of $\mathrm{NH}_{3}$ as an aerosol precursor. While the chemical interactions significantly change the local flux of gaseous $\mathrm{HNO}_{3}$ and $\mathrm{NH}_{4} \mathrm{NO}_{3}$ aerosol, the effect on the total nitrogen flux is small, as this is dominated by the large $\mathrm{NH}_{3}$ emission during this period for which the relative effect is small.

Acknowledgements. Access to the roof of the $47 \mathrm{~m}$ tower was granted by Mr. Deventer from the Physikalisch-Technische Bundesanstalt. L. Thomason provided assistance with the chemical analysis of the VOC tubes at Lancaster University, while K. Gilke, R. Schmelzer, U. Tambor and M. Zerbian from the FAL Braunschweig helped with the analysis of the daily dry denuder/filter pack combinations. This work was funded by the EU projects GRAMINAE and NitroEurope IP.

Edited by: K. Pilegaard

\section{References}

Adams, P. J., Seinfeld, J. H., Koch, D., Micley, L., and Jacob, D.: General circulation assessment of direct radiative forcing by the sulfate-nitrate-ammonium-water inorganic aerosol system, J. Geophys. Res., 106(D1), 1097-1111, 2001.

Allan, J. D., Coe, H., Bower, K. N., Williams, P. I., Gallagher, M. W., Alfarra, M. R., Jimenez, J. L., Nemitz, E., and McDonald, A. G.: Quantitative sampling using the Aerodyne Aerosol Mass Spectrometer. Part 2: Measurements of fine particulate chemical composition in two UK cities., J. Geophys. Res.-Atmos., 108, 4091; doi:4010.1029/2002JD002359, 2003.

Bouwman, A. F., Lee, D. S., Asman, W. A. H., Dentener, F. J., van der Hoek, K. W. and Olivier, J. G. J.: A global highresolution emission inventory for ammonia, Global Biogeochem. Cy., 11(4), 561-587, 1997.

Cruz, C. N., Dassios, K. G. and Pandis, S. N.: The effect of dioctyl phthalate films on the ammonium nitrate aerosol evaporation rate, Atmos. Environ., 34(23), 3897-3905, 2000.

Dal Maso, M., Kulmala, M, Lehtinen, K. E. J., Mäkelä, J. M., Aalto, P., and O'Dowd, C. D.: Condensation and coagulation sinks and formation of nucleation mode particles in coastal and boreal forest boundary layers, J. Geophys. Res., 107(D19), 8097, doi:10.1029/2001JD001053, 2002.

Desjardins, R. L.: Description and evaluation of a sensible heat flux detector, Bound.-Lay. Meteorol., 11, 147-154, 1977.

Dämmgen, U.: Atmospheric nitrogen dynamics in Hesse, Germany: Creating the data base. 2. Atmospheric concentrations of ammonia, its reaction partners and products at Linden, Landbauforschung Völkenrode, 2(57), 157-170, 2007.

Dassios, K. G. and Pandis, S. N.: The mass accommodation coefficient of ammonium nitrate aerosol, Atmos. Environ., 33(18), 2993-3003, 1999. 
David, M., Loubet, B., Cellier, P., Mattsson, M., Schjoerring, J. K., Nemitz, E., Roche, R., Riedo, M., and Sutton M. A.: Ammonia sources and sinks in an intensively managed grassland using dynamic chambers, Biogeosciences, 6, 1625-1655, 2009, http://www.biogeosciences.net/6/1625/2009/.

Dorsey, J. R.: Aspects of biosphere / atmosphere exchange and chemical processing of aerosol, Ph.D. Thesis, University of Manchester Institute of Science and Technology (UMIST), Manchester, UK, 173 pp., 2002.

Dorsey, J. R., Nemitz, E., Gallagher, M. W., Fowler, D., Williams, P. I., Bower, K. N., and Beswick, K. M.: Direct measurements and parameterisation of aerosol flux, concentration and emission velocity above a city, Atmos. Environ, 36(5), 791-800, 2002.

Farquhar, G. D., Firth, P. M., Wetselaar, R., and Weir, B.: On the gaseous exchange of ammonia between leaves and the environment: determination of the ammonia compensation point, Plant Physiol., 66, 710-714, 1980.

Foken, T., Dlugi, R., and Kramm, G.: On the determination of dry deposition and emission of gaseous compounds at the biosphereatmosphere interface, Meteorol. Z., 4(3), 91-118, 1995.

Fowler, D. and Duyzer, J. H.: Micrometeorological techniques for the measurement of trace gas exchange, in: Exchange of trace gases between terrestrial ecosystems and the atmosphere, edited by: Andrea, M. O. and Schimel, D. S., John Wiley \& Sons Ltd., New York, 189-207, 1989.

Fuchs, N. A. and Sutugin, A. G.: Highly dispersed aerosol, in: Topics in Current Aerosol Research, edited by: Hydy, G. M. and Brock, J. R., Pergamon, New York, 160 pp., 1971.

Gallagher, M. W., Nemitz, E., Dorsey, J. R., Fowler, D., Sutton, M. A., Flynn, M., and Duyzer, J.: Measurements and parameterizations of small aerosol deposition velocities to grassland, arable crops and forest: influence of surface roughness length on deposition, J. Geophys. Res., 107(D12), 4154-4163, doi:10.1029/2001JD000817, 2002.

Hensen, A., Nemitz, E., Flynn, M. J., Blatter, A., Jones, S. K., Sørensen, L. L., Hensen, B., Pryor, S., Jensen, B., Otjes, R. P., Cobussen, J., Loubet, B., Erisman, J. W., Gallagher, M. W., Neftel, A., and Sutton, M. A.: Inter-comparison of ammonia fluxes obtained using the relaxed eddy accumulation technique, Biogeosciences Discuss., 5, 3965-4000, 2008, http://www.biogeosciences-discuss.net/5/3965/2008/.

Hoffmann, T., Odum, J. R., Bowman, F., Collins, D., Klockow, D., Flagan, R. C., and Seinfeld, J. H.: Formation of organic aerosol from the oxidation of biogenic hydrocarbons, J. Atmos. Chem., 26, 189-222, 1997.

Holmes, N. S.: A review of particle formation events and growth in the atmosphere in the various environments and discussion of mechanistic implications, Atmos. Environ., 41, 2183-2201, 2007.

Huebert, B. J., Luke, W. T., Delany, A. C. and Brost, R. A.: Measurements of concentrations and dry surface fluxes of atmospheric nitrates in the presence of ammonia, J. Geophys. Res., 93, 7127-7136, 1988.

IPCC: Climate Change 2001 - The scientific basis. Contribution of Working Group I to the Third Assessment Report of the Intergovernmental Panel on Climate Change, Cambridge University Press, New York, 881 pp., 2001.

IPCC: Climate Change 2007 - The Physical Science Basis. Contribution of Working Group I to the Fourth Assessment Report of the IPCC. The Intergovernmental Panel on Climate Change. Cambridge University Press. New York. ISBN 978052188009 1, 1009 pp., 2007.

Karl, T., Guenther, A., Jordan, A., Fall, R., and Lindinger, W.: Eddy covariance measurement of biogenic oxygenated VOC emissions from hay harvesting, Atmos. Environ., 35(3), 491-495, 2001.

Keuken, M. P., Schoonebeek, C. A. M., van Wensveen-Louter, A., and Slanina, J.: Simultaneous sampling of $\mathrm{NH}_{3}, \mathrm{HNO}_{3}, \mathrm{HCl}$, $\mathrm{SO}_{2}$ and $\mathrm{H}_{2} \mathrm{O}_{2}$ in ambient air by a wet annular denuder system, Atmos. Environ., 22, 2541-2548, 1988.

Kirstine, W., Glabally, I., Ye, Y., and Hooper, M.: Emissions of volatile organic compounds (primarily oxygenated species) from pasture, J. Geophys. Res., 103(D9), 10 605-10 619, 1998.

Korhonen, P., Kulmala, M., and Viisanen, Y.: A theoretical study of binary homogenous nucleation of water-ammonium chloride paricles in the atmosphere, J. Aerosol Sci., 28(6), 901-917, 1997.

Kowalski, A. S.: Deliquescence induces eddy covariance and estimable dry deposition errors, Atmos. Environ., 35, 4843-4851, 2001.

Kramm, G., Muller, H., Fowler, D., Hofken, K. D., Meixner, F. X., and Schaller, E.: A Modified Profile Method for Determining the Vertical Fluxes of $\mathrm{NO}, \mathrm{NO}_{2}$, Ozone, and $\mathrm{HNO}_{3}$ in the Atmospheric Surface-Layer, J. Atmos. Chem., 13, 265-288, 1991.

Kulmala, M., dal Maso, M., Mäkelä, J. M., Pirjola, L., Väkevä, M., Aalto, P., Miikkulainen, P., Hämeri, K., and O'Dowd, C. D.: On the formation, growth and composition of nucleation mode particles, Tellus B, 53B(4), 479-490, 2001

Kulmala, M., Vehkamaki, H., Petaja, T., Dal Maso, M., Lauri, A., Kerminen, V.-M., Birmili, W., and McMurry, P. H.: Formation and growth rates of ultrafine atmospheric particles: a review of observations, J. Aerosol Sci., 35(2), 143-176, 2004.

Matthews, E.: Nitrogen fertilisers: global distribution of consumption and associated emissions of nitrous oxide and ammonia, Global Biogeochem. Cy., 8(4), 411-439, 1994.

Milford, C., Theobald, M. R., Nemitz, E., and Sutton, M. A.: Dynamics of ammonia exchange in response to cutting and fertilizing in an intensively-managed grassland, Water Air Soil Poll. Focus, 1, 167-176, 2001.

Milford, C., Theobald, M. R., Nemitz, E., Hargreaves, K. J., Horvath, L., Raso, J., Dämmgen, U., Neftel, A., Jones, S. K., Hensen, A., Loubet, B., Cellier, P., and Sutton, M. A.: Ammonia fluxes in relation to cutting and fertilization of an intensively managed grassland derived from an inter-comparison of gradient measurements, Biogeosciences, 6, 819-834, 2009, http://www.biogeosciences.net/6/819/2009/.

Mozurkewich, M.: The dissociation constant of ammonium nitrate and its dependence on temperature, relative humidity and particle size, Atmos. Environ., 27, 261-270, 1993.

Napari, I., Noppel, M., Vehkamaki, H., and Kulmala, M.: Parameterization of ternary nucleation rates for $\mathrm{H}_{2} \mathrm{SO}_{4}$ $\mathrm{NH}_{3}-\mathrm{H}_{2} \mathrm{O}$ vapors, J. Geophys. Res., 107(D19), 4381, doi:10.1029/2002JD002132, 2002.

Neftel, A., Blatter, A., Hesterberg, R. and Staffelbach, T.: Measurements of concentration gradients of $\mathrm{HNO}_{2}$ and $\mathrm{HNO}_{3}$ over a semi-natural ecosystem, Atmos. Environ., 30, 3017-3025, 1996.

NEGTAP: Transboundary Air Pollution: Acidification, Eutrophication and Group-Level Ozone in the UK. Report of the National Expert Group on Transboundary Air Pollution (NEGTAP) for the UK Department for Environment, Food and Rural Affairs, 
Scottish Executive, The National Assembly for Wales/Cynulliad Cenedlaethol Cymru and the Department of the Environment for Northern Ireland. CEH Edinburgh, 2001.

Nemitz, E. and Sutton, M. A.: Gas-particle interactions above a Dutch heathland: III. Modelling the influence of the $\mathrm{NH}_{3}$ $\mathrm{HNO}_{3}-\mathrm{NH}_{4} \mathrm{NO}_{3}$ equilibrium on size-segregated particle fluxes, Atmos. Chem. Phys., 4, 1025-1045, 2004, http://www.atmos-chem-phys.net/4/1025/2004/.

Nemitz, E., Sutton, M. A., Fowler, D., and Choularton, T.: Application of a $\mathrm{NH}_{3}$ gas-to-particle conversion model to measurement data, in: Poster proceedings of the international conference on atmospheric ammonia, Oxford 2-4 Oct. 1995, edited by: Sutton, M. A., Lee, D. S., Dollard, G. J. and Fowler, D., Institute of Terrestrial Ecology Edinburgh, UK, 98-103, 1996.

Nemitz, E., Sutton, M. A., Wyers, G. P., Otjes, R. P., Schjoerring, J. K., Gallagher, M. W., Parrington, J., Fowler, D., and Choularton, T. W.: Surface/atmosphere exchange and chemical interaction of gases and aerosols over oilseed rape, Agr. Forest Meteorol., 105, 427-445, 2000.

Nemitz, E., Flynn, M., Williams, P. I., Milford, C., Theobald, M. R., Blatter, A., Gallagher, M. W., and Sutton, M. A.: A relaxed eddy accumulation system for the automated measurement of atmospheric ammonia fluxes, Water Air Soil Poll. Focus, 1, 189-202, 2001

Nemitz, E., Gallagher, M. W., Duyzer, J. H., and Fowler, D.: Micrometeorological measurements of particle deposition velocities to moorland vegetation, Q. J. Roy. Meteor. Soc., 128, 22812300, 2002.

Nemitz, E., Sutton, M. A., Wyers, G. P., Otjes, R. P., Mennen, M. G., van Putten, E., Hellemond, J., and Gallagher, M. W.: Gasparticle interactions above a Dutch heathland: II. Concentrations and surface exchange fluxes of atmospheric particles, Atmos. Chem. Phys., 4, 1007-1024, 2004,

http://www.atmos-chem-phys.net/4/1007/2004/.

Nemitz, E., Hargreaves, K. J., Neftel, A., Loubet, B., Cellier, P., Dorsey, J. R., Flynn, M., Hensen, A., Weidinger, T., Meszaros, R., Horvath, L., Dämmgen, U., Frühauf, C., Löpmeier, F. J., Gallagher, M. W., and Sutton, M. A.: Intercomparison and assessment of turbulent and physiological exchange parameters of grassland, Biogeosciences, 6, 1445-1466, 2009a, http://www.biogeosciences.net/6/1445/2009/.

Nemitz, E., Loubet, B., Lehmann, B., Cellier, P., Neftel, A., Jones, S. K., Hensen, A., Ihly, B., Tarakanov, S. V., and Sutton, M. A.: Turbulence characteristics in grassland canopies and implications for tracer transport, Biogeosciences, 6, 1519-1537, 2009b, http://www.biogeosciences.net/6/1519/2009/.

Petroff, A., Mailliat, A., Amielh, M., and Anselmet, F.: Aerosol dry deposition on vegetation canopies. Part I: Review of present knowledge, Atmos. Environ., 42(16), 3625-3653, 2008.

Pio, C. A. and Harrison, R. M.: Vapour pressure of ammonium chloride aerosol: effect of temperature and humidity, Atmos. Environ., 21, 2711-2715, 1987.

Pryor, S. C., Gallagher, M. W., Sievering, H., Larsen, S. E., Barthelmie, R. J., Birsan, F., Nemitz, E., Rinne, J., Kulmala, M., Groenholm, T., Taipale, R., and Vesala, T.: A review of measurement and modelling results of paricle atmosphere-surface exchange, Tellus B, 60, 42-75, 2008.
Reid, R. C., Prausnitz, J. M., and Poling, B. E.: The Properties of Gases and Liquids, 4th Edition, McGraw-Hill, New York, 741 pp., 1987.

Riedo, M., Milford, C., Schmid, M., and Sutton, M. A.: Coupling soil-plant-atmosphere exchange of ammonia with ecosystem functioning in grasslands, Ecol. Model., 158, 83-110, 2002.

Rudolf, R., Vrtala, A., Kulmala, M., Vesala, T., Viisanen, Y., and Wagner, P. E.: Experimental study of sticking probabilities for condensation of nitric acid - water vapor mixtures, J. Aerosol Sci., 32, 913-932, 2001.

Stelson, A. W. and Seinfeld, J. H.: Thermodynamic prediction of the water activity, $\mathrm{NH}_{4} \mathrm{NO}_{3}$ dissociation constant, density and refractive index for the $\mathrm{NH}_{4} \mathrm{NO}_{3}-\left(\mathrm{NH}_{4}\right)_{2} \mathrm{SO}_{4}-\mathrm{H}_{2} \mathrm{O}$ system at $25^{\circ} \mathrm{C}$, Atmos. Environ., 16, 2507-2514, 1982.

Sutton, M. A., Schjorring, J. K., and Wyers, G. P.: Plant - atmosphere exchange of ammonia, Philos. T. R. Soc. S.-A, 351, 261278, 1995.

Sutton, M. A., Milford, C., Nemitz, E., Theobald, M. R., Hill, P. W., Fowler, D., Schjoerring, J. K., Mattson, M. E., Nielsen, K. H., Husted, S., Erisman, J. W., Otjes, R., Hensen, A., Cellier, P., Loubet, B., David, M., Genermont, S., Neftel, A., Blatter, A., Hermann, B., Jones, S. K., Horvath, L., Führer, E., Mantzanas, K., Koukoura, Z., Gallagher, M. W., Williams, P. I., and Riedo, M.: Biosphere-atmosphere interactions of ammonia with grasslands: experimental strategy and results from a new European initiative, Plant Soil, 228(1), 131-145, 2001.

Sutton, M. A., Fowler, D., Moncrieff, J. B., and Storeton-West, R. L.: The exchange of atmospheric ammonia with vegetated surfaces. II: Fertilized vegetation, Q. J. Roy. Meteor. Soc., 119, 1047-1070, 1993.

Sutton, M. A., Nemitz, E., Erisman, J. W., Beier, C., Butterbach Bahl, K., Cellier, P., de Vries, W., Cotrufo, F., Skiba, U., Di Marco, C., Jones, S. K., Laville, P., Soussana, J. F., Loubet, B., Twigg, M., Famulari, D., Whitehead, J., Gallagher, M. W., Neftel, A., Flechard, C. R., Herrmann, B., Calanca, P. L., Schjoerring, J. K., Daemmgen, U., Horvath, L., Tang, Y. S., Emmett, B. A., Tietema, A., Peñuelas, J., Kesik, M., Brueggemann, N., Pilegaard, K., Vesala, T., Campbell, C. L., Olesen, J. E., Dragosits, U., Theobald, M. R., Levy, P., Mobbs, D. C, Milne, R., Viovy, N., Vuichard, N., Smith, J. U., Smith, P. E., Bergamaschi, P., Fowler, D., and Reis, S.: Challenges in quantifying biosphereatmosphere exchange of nitrogen species, Environ. Pollut., 150, 125-139, 2007.

Sutton, M. A., Nemitz, E., Theobald, M. R., Milford, C., Dorsey, J. R., Gallagher, M. W., Hensen, A., Jongejan, P. A. C., Erisman, J. W., Mattsson, M. E., Schjoerring, J. K., Cellier, P., Loubet, B., Roche, R., Neftel, A., Herrmann, B., Jones, S., Lehman, B. E., Horvath, L., Weidinger, T., Rajkai, K., Burkhardt, J., Löpmeier, F. J., and Daemmgen, U.: Dynamics of ammonia exchange with cut grassland: Strategy and implementation of the GRAMINAE Integrated Experiment, Biogeosciences, 6, 309-331, 2009a, http://www.biogeosciences.net/6/309/2009/.

Sutton, M. A., Nemitz, E., Milford, C., Campbell, C., Erisman, J. W., Hensen, A., Cellier, P., David, M., Loubet, B., Personne, E., Schjoerring, J. K., Mattsson, M. E., Dorsey, J. R., Gallagher, M.W., Horvath, L., Weidinger, T., Dämmgen, U., Neftel, A., Herrmann, B., Lehman, B. E. Flechard, C., and Burkhardt, J.: Dynamics of ammonia exchange with cut grassland: synthesis of results and conclusions of the GRAMINAE Integrated Exper- 
iment, Biogeosciences Discuss., 6, 1121-1184, 2009b, http://www.biogeosciences-discuss.net/6/1121/2009/.

ten Brink, H. M., Veefkind, J. P., Waijers-Ijpelaan, A., and van der Hage, J. C.: Aerosol light-scattering in the Netherlands, Atmos. Environ., 30, 4251-4261, 1996.

Thomas, R. M., Trebs, I., Otjes, R., Jongejan, P. A. C., ten Brink, H., Phillips, G., Kortner, M., Meixner, F. X., and Nemitz, E.: An automated analyzer to measure surface-atmosphere exchange fluxes of water soluble inorganic aerosol compounds and reactive trace gases, Environ. Sci. Technol., 43(5), 1412-1418, 2009.

Umweltbundesamt: Jahresbericht 2000 des Messnetzes, UBA Texte 77-01, Umweltbundesamt, Berlin, 174 pp., 2001.

van Oss, R., Duyzer J., and Wyers, P.: The influence of gas-toparticle conversion on measurements of ammonia exchange over forest, Atmos. Environ., 32(3), 465-471, 1998.

Verheggen, B. and Mozurkewich, M.: Determination of nucleation and growth rates from measurements of atmospheric aerosol size distributions, J. Aerosol Sci., 31(Suppl. 1), S446-S447, 2000.

Vestreng, V. and Støren, E.: Analysis of UN ECE/EMEP emission data. MSC-W Status Report 2000. Oslo, Norwegian Meteorological Institute (EMEP MSC-W Note 1/00) (DNMI Research Note 37), 2000.
Vong, R. J., Vickers, D., and Covert, D. S.: Eddy correlation measurements of aerosol deposition to grass, Tellus B, 56B, 105117, 2004.

Wesely, M. L., Cook, D. R., Hart, R. L., and Speer, R. E.: Measurements and parameterization of particulate sulfur dry deposition over grass, J. Geophys. Res.-Atmos., 90, 2131-2143, 1985.

Wexler, A. S. and Seinfeld, J. H.: The distribution of ammonium salts among size and composition dispersed aerosol, Atmos. Environ., 24, 1231-1246, 1990.

Wiebe, H. A., Anlauf, K. G., Tuazon, E. C., Winer, A. M., Biermann, H. W., Appel, B. R., Solomon, P. A., Cass, G. R., Ellestad, T. G., Knapp, K. T., Peake, E., Spicer, C. W., and Lawson, D. R.: A comparison of measurements of atmospheric ammonia by filter packs, transition flow reactors, simple and annular denuders and Fourier transform infrared spectroscopy, Atmos. Environ., 24, 1019-1028, 1990.

Williams, P. I.: Construction and validation of a DMPS for aerosol charaterization, Ph.D. Thesis, University of Manchester Institute of Science and Technology, Manchester, U.K., 1999.

Zimmerling, R., Dämmgen, U., Haenel, H. D., Kusters, A., Max, W., and Jager, H. J.: The classifying ratiometric method for the continuous determination of atmospheric flux densities of reactive N- and S-species with denuder filter systems, Angew. Bot., 71(1-2), 38-49, 1997. 